\title{
The impacts of drainage, nutrient status and management practice on the full carbon balance of grasslands on organic soils in a maritime temperate zone
}

\author{
F. Renou-Wilson ${ }^{1}$, C. Barry ${ }^{2}$, C. Müller ${ }^{1,3}$, and D. Wilson ${ }^{4}$ \\ ${ }^{1}$ School of Biology and Environmental Science, Science West Centre, University College Dublin, Belfield, Dublin 4, Ireland \\ ${ }^{2}$ Agri-Food \& Biosciences Institute, Newforge Lane, Belfast BT9 5PX, UK \\ ${ }^{3}$ Institute for Plant Ecology, Justus Liebig University Giessen, Germany \\ ${ }^{4}$ Earthy Matters Environmental Consultants, Glenvar, Letterkenny, Co. Donegal, Ireland
}

Correspondence to: F. Renou-Wilson (florence.renou@ucd.ie)

Received: 25 February 2014 - Published in Biogeosciences Discuss.: 11 April 2014

Revised: 4 July 2014 - Accepted: 4 July 2014 - Published: 19 August 2014

\begin{abstract}
Temperate grasslands on organic soils are diverse due to edaphic properties but also to regional management practices and this heterogeneity is reflected in the wide range of greenhouse gas (GHG) flux values reported in the literature. In Ireland, most grasslands on organic soils were drained several decades ago and are managed as extensive pastures with little or no fertilisation. This study describes a 2-year study of the net ecosystem carbon balance (NECB) of two such sites. We determined GHG fluxes and waterborne carbon $(\mathrm{C})$ emissions in a nutrient-rich grassland and compared it with values measured from two nutrient-poor organic soils: a deep-drained and a shallow-drained site. Carbon dioxide $\left(\mathrm{CO}_{2}\right)$, methane $\left(\mathrm{CH}_{4}\right)$ and nitrous oxide $\left(\mathrm{N}_{2} \mathrm{O}\right)$ fluxes were determined using the chamber technique, and fluvial $\mathrm{C}$ fluxes were estimated by combining drainage water concentrations and flows.
\end{abstract}

The nutrient-rich site was an annual source of $\mathrm{CO}_{2}$ (233 $\left.\mathrm{g} \mathrm{C} \mathrm{m}^{-2} \mathrm{yr}^{-1}\right), \mathrm{CH}_{4}$ neutral, and a small source of $\mathrm{N}_{2} \mathrm{O}\left(0.16 \mathrm{~g} \mathrm{~N}_{2} \mathrm{O}-\mathrm{N} \mathrm{m}^{-2} \mathrm{yr}^{-1}\right)$. Net ecosystem exchange (NEE) at the shallow-drained nutrient-poor site was -89 and $-99 \mathrm{~g} \mathrm{C} \mathrm{m}^{-2} \mathrm{yr}^{-1}$ in Years 1 and 2 respectively, and NEE at the deep-drained nutrient-poor site was 85 and $-26 \mathrm{~g} \mathrm{C} \mathrm{m}^{-2} \mathrm{yr}^{-1}$ respectively. Low $\mathrm{CH}_{4}$ emissions $\left(1.3 \mathrm{~g} \mathrm{C} \mathrm{m}^{-2} \mathrm{yr}^{-1}\right)$ were recorded at the shallow-drained nutrient-poor site. Fluvial exports from the nutrient-rich site totalled $69.8 \mathrm{~g} \mathrm{C} \mathrm{m}^{-2} \mathrm{yr}^{-1}$ with $54 \%$ as dissolved organic $\mathrm{C}$. Waterborne $\mathrm{C}$ losses from the nutrient-poor site reflected dif- ferences in annual runoff totalling $44 \mathrm{~g} \mathrm{C} \mathrm{m}^{-2} \mathrm{yr}^{-1}$ in Year 1 and $30.8 \mathrm{~g} \mathrm{C} \mathrm{m}^{-2} \mathrm{yr}^{-1}$ in Year 2 .

The NECB of the nutrient-rich grassland was $663 \mathrm{~g} \mathrm{C} \mathrm{m}^{-2} \mathrm{yr}^{-1}$ with biomass exports being the major component accounting for $53 \%$. The NECB of the nutrient-poor deep-drained site was less than half of the nutrient-rich site (2-year mean $267 \mathrm{~g} \mathrm{C} \mathrm{m}^{-2} \mathrm{yr}^{-1}$ ). Although $\mathrm{NEE}$ at the nutrient-poor shallow-drained site was negative in both years, high biomass export meant it was a net $\mathrm{C}$ source (2-year mean NECB $103 \mathrm{~g} \mathrm{C} \mathrm{m}^{-2} \mathrm{yr}^{-1}$ ). While the impacts of the nutrient and drainage status on NEE, biomass exports and fluvial $\mathrm{C}$ losses were confirmed, inter-regional differences in management practice and climate were also significant factors which impacted on the overall NECB of these ecosystems. Contrary to expectation, the NECB of nutrient-poor drained organic soils under grasslands is not necessarily a large $\mathrm{C}$ source and this has implications for Ireland's choice of national GHG inventory reporting methodologies. This study can also aid the development of strategies to deliver reduced emissions tailored to local grassland types.

\section{Introduction}

Organic soils are characterised by a high content of partially decomposed organic matter and are an important component of terrestrial carbon (C) storage (Gorham, 1991; Garnett et 
al., 2001). Drained peatlands and peat fires are responsible for almost one-quarter of $\mathrm{C}$ emissions from the land use sector with at least 2 Gigatonnes $(\mathrm{Gt})$ of carbon dioxide $\left(\mathrm{CO}_{2}\right)$ emitted to the atmosphere globally each year (Parish et al., 2008; FAO, 2013a). In Europe, $20 \%$ of all $\mathrm{CO}_{2}$ emissions between 1990 and 2010 originated from drained organic soils (FAO, 2013b).

In Ireland, organic soils contain an estimated $1-1.5 \mathrm{Gt}$ of $\mathrm{C}$, which represents between 62 and $75 \%$ of the total soil C pool (Tomlinson, 2005; Eaton et al., 2008; RenouWilson et al., 2011). However, this C store is under threat as centuries of peatland exploitation (peat extraction, agriculture and forestry) have left only ca. $15 \%$ of peat soils in a natural state (Renou-Wilson et al., 2011). Carbon emissions $\left(\mathrm{CO}_{2}\right.$ and methane, $\left.\mathrm{CH}_{4}\right)$ from Irish peat soils and related activities are estimated to account for ca. $3 \mathrm{MtC}$ per year (Wilson et al., 2013b), equivalent to the emissions reported from the transport sector (Duffy et al., 2013). Therefore, managing organic soils as a means of mitigating greenhouse gas (GHG) emissions from agricultural systems can be an effective strategy for lowering national emissions (Dawson and Smith, 2007; Smith et al., 2007). Of note, a new activity called "rewetting and drainage" of organic soils has been included in the next post-Kyoto Protocol commitment period (2013-2017). New guidelines, together with default emission factors, have been developed for the 2013 Wetland Supplement of the Intergovernmental Panel on Climate Change (IPCC, 2014).

The use of organic soils for agriculture is a contentious land-use option when considering atmospheric impacts. In Ireland, agriculture is the largest contributor to overall national emissions and accounted for $32.1 \%$ in 2012 (Duffy et al., 2013), which is the greatest proportion among EU Member States (Eurostat, 2013). Grassland is the predominant land use in the temperate zone and covers $60 \%$ of the land area of Ireland (EPA, 2008). The reclamation of raw peat soils or cutover peat soils for grassland was a direct result of population pressures in the 19th century which intensified in the 20th century due to national drainage acts and agricultural schemes (Feehan et al., 2008). Presently, some 300000 ha of organic soils is under grassland (with negligible area cultivated for crops), on par with organic soils drained for forestry and, together with industrial cutaway peatlands, managed peatlands represent nearly half of the total peat soil area or $10 \%$ of the total land area (Wilson et al., 2013b).

Drainage and grassland management practices (e.g. fertilisation) of organic soils stimulate the aerobic oxidation of previously accumulated organic matter, promoting $\mathrm{CO}_{2}$ and nitrous oxide $\left(\mathrm{N}_{2} \mathrm{O}\right)$ emissions while reducing methanogenesis (Byrne et al., 2004; Freibauer et al., 2004; Nieveen et al., 2005; Jacobs et al., 2007; Elsgaard et al., 2012; Drösler et al., 2013; Schrier-Uijl et al., 2013). However, inter-regional spatio-temporal variability of $\mathrm{CO}_{2}$ flux is high, particularly in western Europe. The implication is that physical and bio- geochemical soil conditions (nutrient content, organic matter quality and water table levels) as well as local management practices and subtle climatic variations exert strong influences on C loss (Drösler et al., 2008). In addition, drainage of temperate organic soils typically leads to higher dissolved organic C (DOC) fluxes (Wallage et al., 2006; Urbanová et al., 2011), so that management practices may alter both contemporary photosynthetic uptake rates, but also the stability of older soil stores of sequestered C. Further, although fluvial $\mathrm{C}$ exports are increasingly recognised as potentially significant components of terrestrial $\mathrm{C}$ balances, full accounting of all fluvial $\mathrm{C}$ forms remains the exception rather than the rule, notably for dissolved inorganic and particulate organic $\mathrm{C}$.

The annual GHG emissions from organic soils under grassland are currently evaluated in Ireland using the generic Tier 1 reporting method (IPCC, 2006). These emission factors typically rely on assessing and averaging available data and so can be biased towards locations with high research activities, and therefore individual regional climatic and edaphic conditions where such research is conducted. For example, grasslands on organic soils in Germany, where much research on grassland GHG balances is conducted, are typically fertilised, deep-drained and nutrient-rich (Drösler et al., 2008, 2013), whereas in Ireland, extensively grazed permanent pasture with partial drainage is common. The primary objective of this study is to estimate annual net $\mathrm{CO}_{2}, \mathrm{CH}_{4}$ and $\mathrm{N}_{2} \mathrm{O}$ fluxes as well as fluvial $\mathrm{C}$ fluxes from two typical Irish grasslands over organic soil. We further combine estimates of terrestrial net ecosystem exchange (NEE), fluvial C export, and $\mathrm{CH}_{4}$ fluxes associated with grazing livestock, as well as biomass $\mathrm{C}$ export, to calculate the net ecosystem $\mathrm{C}$ balance (NECB). By comparing two grasslands with contrasting drainage, soil nutrient status and management practices, we assess the role of these attributes in respect to biomass productivity, GHG and waterborne C fluxes, and appraise the hypothesis that specific site characteristics (low soil fertility and higher water table levels), management systems (low stocking density and low inputs) and regional climate can affect the overall $\mathrm{C}$ balance of these ecosystems. Finally, this study provides data to support a progression towards the IPCC Tier 2 reporting level in Ireland by producing emission factors (EFs) for $\mathrm{CO}_{2}, \mathrm{CH}_{4}, \mathrm{~N}_{2} \mathrm{O}$ and DOC for typical organic soils under grassland.

\section{Material and methods}

\subsection{Study sites}

The study sites were located in a maritime temperate climate zone in two distinct Irish ecoregions, both characterised as landscapes rich in organic soils. Site A at Glenvar, Co. Donegal (latitude: $55^{\circ} 9^{\prime} \mathrm{N}$, longitude: $7^{\circ} 34^{\prime} \mathrm{W}$ ) is situated at $40 \mathrm{~m}$ elevation in the northwest of the country, less than $1 \mathrm{~km}$ from the sea shore, and the climate is typical of western maritime 
Table 1. Selected climatic data from two research locations during Year 1 (April 2011 to March 2012) and Year 2 (April 2012 to March 2013) and compared with the 30-year average (1981-2010) (Met Eireann, 2013).

\begin{tabular}{lrr}
\hline & Site A & Site B \\
\hline Precipitation $(\mathrm{mm})$ & & \\
\hline Year 1 & 1211 & 1003 \\
Year 2 & 1193 & 1081 \\
30-year average & 1076 & 941 \\
\hline Air temperature ${ }^{\circ} \mathrm{C}$ & & \\
\hline Year 1 (min; max) & $10.2(-3.6 ; 23.4)$ & $9.6(-6.6 ; 24.1)$ \\
Year 2 (min; max) & $9.7(-1.7 ; 22.6)$ & $8.4(-6.3 ; 26)$ \\
30-year average & $9.8(-1 ; 17.4)$ & $9.1(-3.2 ; 18)$ \\
\hline
\end{tabular}

Ireland with warm winters (very few ground frosts) but cool summers. Site B in Lanesborough, Co. Longford (latitude: $53^{\circ} 39^{\prime} \mathrm{N}$, longitude: $7^{\circ} 56^{\prime} \mathrm{W}$ ) is also low-lying, situated at $38 \mathrm{~m}$ elevation but is typical of the midlands landscape, with late spring frosts occurring as late as the beginning of June. Despite comparable long-term annual mean temperatures, lower minimum and higher maximum temperatures are typically recorded at Site B. A minor gradient in precipitation is also present with higher mean rainfall in Site A (Table 1). Potential evapo-transpiration in that region is estimated at $32-36 \%$ of annual precipitation (estimated long-term annual runoff of ca. $700 \mathrm{~mm}$ ), compared to $44 \%$ (annual runoff, ca. $586 \mathrm{~mm}$ ) for Site B (Mills, 2000).

Land use in both regions is predominantly grassland and the two sites are managed for low intensity beef suckler production. Site A has a lower stocking density of 0.6 Livestock Units (L.U.) per ha (all suckler cows) compared to Site B with 1.2 L.U. (sheep in the winter months and suckler cows and calves in the summer months). While Site A only receives on-site organic fertilisation from manure directly deposited by cattle in the field, artificial fertiliser is usually applied in spring to Site $\mathrm{B}$ at a rate of $25 \mathrm{~kg} \mathrm{Nha}^{-1}$. However, no fertilisation took place at Site B during the first monitoring year. No cows are present on-site during the winter months and no concentrates or additional feeding occur on site.

Both Sites A and B have been drained for over 60 years and the soils are categorised as terric and limnic histosols respectively (FAO, 1998). With an organic matter content higher than $30 \%$ (Table 2) over a depth greater than $40 \mathrm{~cm}$, they satisfy the definition of peat soils in both the Irish soil classification (Hammond, 1981) and the FAO key to soil types (FAO, 1998), which form the basis of definitions used in the IPCC guidelines (IPCC, 2006, 2014). They are typical "earthy peat", i.e. reclaimed drained peat soils characterised by a well aerated structure and a relatively firm surface horizon containing few or no recognisable plant remains. The peat in Site A overlies bedrock of Precambrian schist and gneiss and contains on average $20 \% \mathrm{C}$ (Table 2). The base geology of Site B is of limestone origin and the overlying peat has a higher $\mathrm{pH}(5.5)$ and almost double the $\mathrm{C}$ content $(40 \%)$ and is situated over a thick layer of marl (pH 7.2). Despite similar $\mathrm{C}: \mathrm{N}$ ratios (16-21), Sites A and B differ in nutrient status and, based on $\mathrm{N}$, phosphorus $(\mathrm{P})$ and potassium (K) content, Site A is nutrient-poor while Site B is nutrientrich (Table 2).

Site B has a uniform hydrological soil profile throughout the experimental area. In contrast, Site A can be divided into two distinct sub-sites: a deep-drained area "Site $A_{\mathrm{d}}$ " (defined in the 2006 IPCC guidelines as the mean annual water table depth of $30 \mathrm{~cm}$ and deeper below the surface) and a shallowdrained area "Site $A_{\mathrm{s}}$ " (defined as the mean annual water table depth of less than $30 \mathrm{~cm}$ below the surface).

\subsection{Vegetation}

Both sites displayed a moderate to low quality sward dominated by Holcus lanatus and Agrostis spp. Wetland species, such as Equisetum palustre, Juncus effusus and Juncus articulatus were present in the shallow-drained Site $A_{\mathrm{s}}$ while Site B was characterised by a greater cover of Rumex acetosa and Cirsium arvensis. While the moss layer was almost non-existent in Site B, Site $A_{\mathrm{d}}$ and $A_{\mathrm{s}}$ had an average ground cover of 20 and $60 \%$ respectively, composed solely of Rhytidiadelphus squarrosus. Experimental plots were fenced off from cattle for the duration of the study. To simulate local activities, the vegetation within and surrounding each collar for GHG measurements was cut to a stubble height of $5 \mathrm{~cm}$ in order to mimic the cow grazing regime, so that the height of the vegetation was always comparable to that in the grazed fields. The interval between cuttings (considered as grazing events) was not strict but rather followed the concomitant status of the vegetation in the fields. The number of cuttings also varied each year reflecting the biomass production. The vegetation was collected from each plot and oven dried to a constant mass at $75^{\circ} \mathrm{C}$. $\mathrm{C}$ and $\mathrm{N}$ contents were measured (CE440 Exeter Elemental Analyser) using a pooled, homogenised sample of all biomass cut from each plot from the first growing season. Vegetation height $(\mathrm{cm})$ was measured regularly throughout the year and systematically during GHG measurements and before cutting events. Conjunctly, leaf area index (LAI) was measured at each plot when photosynthetic photon flux density (PPFD) levels were sufficient (November-March excluded). The AccuPAR LP-80 (Ceptometer, Decagon Instruments, WA, USA) was used to measure light interception via 80 independent photo sensors. The PPFD transmission data were used to calculate gap fractions which were inverted to derive LAI estimates (Norman and Campbell, 1989). Polynomial regression constrained to pass through the origin was used to develop site-specific relationships between vegetation height and LAI (Fig. 1) for use in Eq. (1) (see below). 
Table 2. Soil and land use characteristics of the research sites.

\begin{tabular}{|c|c|c|c|}
\hline & \multicolumn{2}{|c|}{ Site A } & Site B \\
\hline Location in Ireland & \multicolumn{2}{|c|}{ Northwest, Atlantic coast } & Midlands \\
\hline Latitude; longitude & \multicolumn{2}{|c|}{$55^{\circ} 9^{\prime} \mathrm{N} ; 7^{\circ} 34^{\prime} \mathrm{W}$} & $53^{\circ} 39^{\prime} \mathrm{N} ; 7^{\circ} 56^{\prime} \mathrm{W}$ \\
\hline Soil description & \multicolumn{2}{|c|}{ Terric histosol } & Limnic histosol \\
\hline Fertility & \multicolumn{2}{|c|}{ Nutrient-poor } & Nutrient-rich \\
\hline Drainage & $\begin{array}{l}\text { Deep-drained } \\
\text { Site } A_{\mathrm{d}}\end{array}$ & $\begin{array}{l}\text { Shallow-drained } \\
\text { Site } A_{\mathrm{S}}\end{array}$ & Deep-drained \\
\hline $\mathrm{pH}$ (in water) & 4.73 & 4.93 & 5.50 \\
\hline $\begin{array}{l}\text { Bulk density } \\
\left(\mathrm{g} \mathrm{cm}^{-3}\right)\end{array}$ & 0.41 & 0.47 & 0.31 \\
\hline OM \% (LOI) & 30 & 42 & 70 \\
\hline $\mathrm{C} \% *$ & 17.4 & 23.1 & 38.1 \\
\hline $\mathrm{N} \% *$ & 1.09 & 1.10 & 2.25 \\
\hline $\mathrm{C}: \mathrm{N}$ & 16 & 21 & 17 \\
\hline $\begin{array}{l}\text { Carbon density } \\
\left(\mathrm{gC} \mathrm{dm}^{-3}\right)\end{array}$ & 71.3 & 108.5 & 124.3 \\
\hline $\begin{array}{l}\text { Nitrogen density } \\
\left(\mathrm{g} \mathrm{N} \mathrm{dm}^{-3}\right)\end{array}$ & 4.5 & 5.2 & 7.0 \\
\hline $\mathrm{P} \%$ & 0.14 & 0.13 & 0.24 \\
\hline $\mathrm{K}(\mathrm{ppm})$ & 197 & 188 & 278 \\
\hline $\mathrm{NH}_{4}-\mathrm{N}\left(\mathrm{mg} \mathrm{L}^{-1}\right)$ & nd & nd & 0.51 \\
\hline $\mathrm{NO}_{3}-\mathrm{N}\left(\mathrm{mg} \mathrm{L}^{-1}\right)$ & 0.99 & 0.42 & 2.61 \\
\hline Vegetation: dominant species & $\begin{array}{l}\text { Holcus lanatus, Agrostis } \\
\text { stolonifera, Epilobium } \\
\text { angustifolium }\end{array}$ & $\begin{array}{l}\text { As Site } A_{\mathrm{d}}+\text { Equisetum } \\
\text { palustre, Juncus effusus, } \\
\text { Juncus articulatus in } \\
\text { some plots }\end{array}$ & $\begin{array}{l}\text { Holcus lanatus, Agrostis stolonifera, } \\
\text { Rumex acetosa, Cirsium arvensis, } \\
\text { Phleum pratense }\end{array}$ \\
\hline
\end{tabular}

$\mathrm{C}$ - carbon; $\mathrm{N}$ - nitrogen; $\mathrm{P}$ - phosphorus; $\mathrm{K}$ - potassium. $\mathrm{OM}$ - organic matter; LOI (Loss-on-ignition); nd - not detectable. ${ }^{*} \mathrm{C}$ and $\mathrm{N}$ were directly measured using Exeter Analytical CE440 CHN elemental analyser.

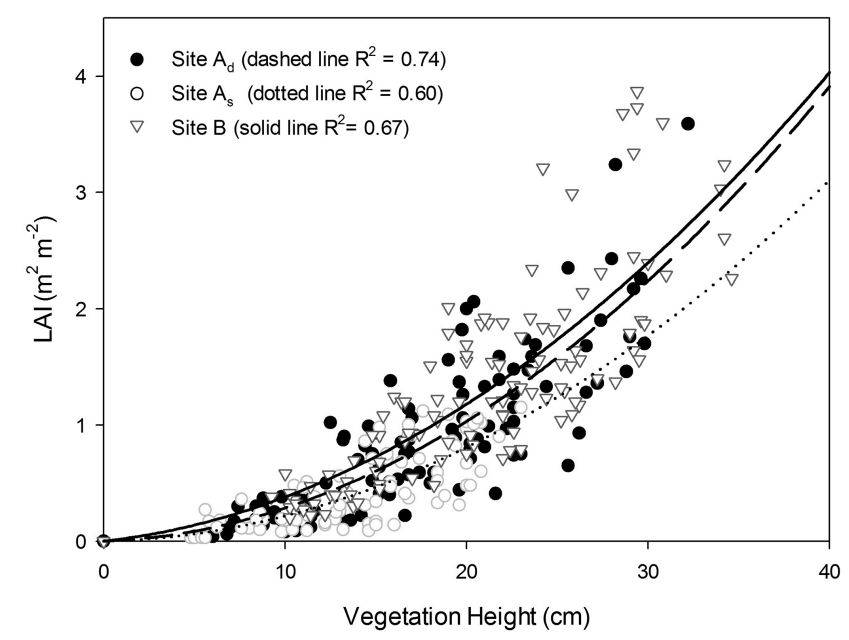

Figure 1. Relationships between vegetation height $(H)$ and leaf area index (LAI); the equations for the fitted regression lines are for Site $A_{\mathrm{d}}$ : $\mathrm{LAI}=0.0023 \times H^{2}+0.0056 \times H$; Site $A_{\mathrm{s}}:$ LAI $=\mathrm{LAI}=0.0019 \times H^{2}+0.003 \times H$ and Site B: $\mathrm{LAI}=0.0021 \times H^{2}+0.0171 \times H$.

\subsection{Greenhouse gas sampling}

Twelve permanent sample plots were established systematically within Site A ( $n=7$ for Site $A_{\mathrm{d}}, n=5$ for Site $\left.A_{\mathrm{s}}\right)$ and nine sample plots at Site B (at least $15 \mathrm{~m}$ from field border or river). Each sample plot consisted of a stainless steel collar $(60 \times 60 \mathrm{~cm})$ that was inserted to a depth of $20 \mathrm{~cm}$ into the soil prior to the start of the study. Perforated PVC pipes (internal diameter: $2 \mathrm{~cm}$ ) were inserted adjacent to each sample plot to measure water table position (WT). Wooden boardwalks were built around the sample plots to minimise damage to the vegetation and to avoid compression of the peat during gas sampling. Data loggers (Hobo External Data Loggers, Onset Computer Corporation, MA, USA) were established at each study site and recorded hourly soil temperatures $\left({ }^{\circ} \mathrm{C}\right)$ at 5, 10 and $20 \mathrm{~cm}$ depths. A weather station (Watch Dog Model 2400, Spectrum Technologies Inc., IL, USA) was established at each site and recorded PPFD $\left(\mu \mathrm{mol} \mathrm{m} \mathrm{m}^{-2} \mathrm{~s}^{-1}\right)$, soil temperatures $\left({ }^{\circ} \mathrm{C}\right)$ at 5 and $10 \mathrm{~cm}$ depths, hourly rainfall $(\mathrm{mm})$ and volumetric soil moisture at $5 \mathrm{~cm}(\%$, Site B only).

Site A was monitored starting April 2011 (first 2 years are reported here) while Site B was only monitored for 1 year (April 2011 to March 2012) with no fertiliser application taking place during that time. Additional $\mathrm{N}_{2} \mathrm{O}$ measurements 
were taken at Site B in April-June 2012 during an intensive campaign after a typical fertilisation event of $25 \mathrm{~kg} \mathrm{~N} \mathrm{ha}^{-1}$.

\subsection{1 $\mathrm{CO}_{2}$ flux measurements}

$\mathrm{CO}_{2}$ fluxes were measured from April 2011 to March 2013 (Site A) and from April 2011 to March 2012 (Site B) at fortnightly (summer) and monthly (winter) intervals using the static chamber method (Alm et al., 2007). Measurements were done between 8 a.m. and 6 p.m. ( 2 to 9 measurements per collar per day). Instantaneous NEE was measured over a range of PPFD using a transparent polycarbonate chamber $(60 \times 60 \times 33 \mathrm{~cm})$ equipped with internal fans to ensure mixing of the air and a cooling system to maintain the temperature within the chamber close to the ambient air temperature (see Alm et al., 2007). For each measurement, the chamber was placed in a water-filled channel at the top of the collar and $\mathrm{CO}_{2}$ concentration (ppmv) in the chamber headspace was measured at $15 \mathrm{~s}$ intervals over a period of $60-180 \mathrm{~s}$ using a portable $\mathrm{CO}_{2}$ analyser (EGM-4) (PP Systems, UK). PPFD was measured by a quantum sensor located at the top of the chamber (PAR-1. PP Systems). Concurrently, air temperature $\left({ }^{\circ} \mathrm{C}\right)$ within the chamber and soil temperatures at 5,10 and $20 \mathrm{~cm}$ depths were recorded at each collar (soil temperature probe; ELE International, UK). The WT position relative to the soil surface was manually measured with a water level probe (Eijkelkamp Agrisearch Equipment, the Netherlands). Following each NEE measurement, the chamber was vented for a short time by removing it from the collar. This was carried out in order to ensure equilibration of the gas concentration. The chamber was then replaced in the collar and covered with an opaque material in order to provide an estimate of ecosystem respiration $\left(R_{\text {eco }}\right)$, which is the sum of heterotrophic and autotrophic respiration enclosed by the chamber. Flux rates $\left(\mathrm{mg} \mathrm{CO}_{2} \mathrm{~m}^{-2} \mathrm{~h}^{-1}\right)$ were calculated as the linear slope of the $\mathrm{CO}_{2}$ concentration in the chamber headspace over time, with respect to the chamber volume, collar area and air temperature. A flux was accepted if the coefficient of determination $\left(r^{2}\right)$ was at least 0.90 . An exception was made in cases where the flux was close to zero (mainly in winter time where soil/plant processes are typically slower) and the $r^{2}$ is always low (Alm et al., 2007; Görres et al., 2014). In these cases ( $\sim 2 \%$ of total fluxes) the flux data were examined graphically and fluxes with obvious non-linearity (due to chamber leakage, fan malfunction etc.) were discarded. The remainder were accepted provided that some of the environmental variables measured at the same time (e.g. soil temperature, PPFD, LAI) were sufficiently low to account for the low flux values (e.g Wilson et al., 2013a). Gross primary production (GPP) was calculated as the sum of NEE and $R_{\text {eco }}$ values (Alm et al., 2007).

\subsection{2 $\mathrm{CH}_{4}$ and $\mathrm{N}_{2} \mathrm{O}$ flux measurements}

$\mathrm{CH}_{4}$ and $\mathrm{N}_{2} \mathrm{O}$ fluxes were measured at fortnightly/monthly intervals using the static chamber method, which consisted of an opaque, polycarbonate chamber $(60 \times 60 \times 25 \mathrm{~cm})$ equipped with a battery-operated fan, which mixed the air within the chamber headspace. Four $50 \mathrm{~mL}$ samples were withdrawn into $60 \mathrm{~mL}$ polypropylene syringes from the chamber headspace at $10 \mathrm{~min}$ intervals over a $40 \mathrm{~min}$ period (first sample taken $10 \mathrm{~min}$ after chamber closure) and then injected into pre-evacuated Exetainers ${ }^{\circledR}$ vials $(12 \mathrm{~mL}$ Soda Glass Vials, Labco, UK). During each measurement, air temperature inside the chamber, soil temperature (at 5, 10 and $20 \mathrm{~cm}$ depths) and WT were recorded at each collar. Gas samples were sent to Justus-Liebig Universität Gießen, Germany for analysis. The samples were analysed for $\mathrm{CO}_{2}, \mathrm{CH}_{4}$ and $\mathrm{N}_{2} \mathrm{O}$ concentrations with a gas chromatograph (Bruker Greenhouse Gas Analyzer 450-GC) equipped with a thermal conductivity detector (TCD), a flame ionisation detector (FID) and an electron capture detector (ECD). Detector temperatures were $200^{\circ} \mathrm{C}$ (TCD), $300^{\circ} \mathrm{C}$ (FID) and $300^{\circ} \mathrm{C}$ (ECD). The $\mathrm{CO}_{2}(304,402,1509,4000$ and $20005 \mathrm{ppm})$, $\mathrm{CH}_{4}(1.02,1.81,5.02,20.9$ and $101.9 \mathrm{ppm})$ and $\mathrm{N}_{2} \mathrm{O}$ standards $(0.25,0.32,2.01 .15 .1$ and $100.1 \mathrm{ppm})$ standards were supplied by Deuste Steininger GmbH. Gas peaks were integrated using Galaxie software (Varian Inc. 2006). Fluxes $\left(\mathrm{mgCH} \mathrm{CH}_{4} \mathrm{~m}^{-2} \mathrm{~h}^{-1}\right.$ and $\mu \mathrm{g} \mathrm{N}_{2} \mathrm{O} \mathrm{m}^{-2} \mathrm{~h}^{-1}$ ) were calculated from the linear change in gas concentration as a function of time, chamber volume, collar area and air temperature. A flux was accepted if the coefficient of determination $\left(r^{2}\right)$ was at least 0.90 . The same criteria applied to $\mathrm{CO}_{2}$ in regard to low fluxes were also applied to $\mathrm{CH}_{4}$ and $\mathrm{N}_{2} \mathrm{O}$ fluxes. Approximately $32 \%$ of $\mathrm{CH}_{4}$ fluxes and $15 \%$ of $\mathrm{N}_{2} \mathrm{O}$ fluxes were discarded for obvious non-linear changes over the measurement period. Positive flux values indicated a loss of $\mathrm{CH}_{4}$ and $\mathrm{N}_{2} \mathrm{O}$ to the atmosphere and negative flux values indicated $\mathrm{CH}_{4}$ and $\mathrm{N}_{2} \mathrm{O}$ uptake.

\subsection{3 $\mathrm{CO}_{2}$ flux modelling}

Statistical and physiological response models (Alm et al., 2007) were constructed and parameterised for each study site. Model evaluation was based on the following criteria; (a) statistically significant model parameters $(p<0.05)$, (b) lowest possible standard error of the model parameters and (c) highest possible coefficient of determination (adjusted $r^{2}$ ) (see Laine et al., 2009). Given the homogeneous dominant vegetation within each study site, we combined data from all sample plots $(n=12$ at Site A and $n=9$ at Site B) to construct a single model for gross photosynthesis (GPP) and ecosystem respiration ( $\left.R_{\text {eco }}\right)$ for each site. Model coefficients were estimated using the Levenberg-Marquardt multiple non-linear regression technique (IBM SPSS Statistics for Windows, Version 21.0. Armonk, NY, USA). One-third of the data was randomly removed from all data sets prior to 
modelling and used to independently test the models. During model construction, the relationship between GPP or $R_{\text {eco }}$ and a range of independent environmental variables (recorded in conjunction with flux measurements) was tested. Only variables that increased the explanatory power of the model were included. The models were accepted if the residuals were evenly scattered around zero. In the GPP models, we used PPFD and LAI as explanatory variables:

$\mathrm{GPP}=P_{\max }\left(\frac{\mathrm{PPFD}}{\mathrm{PPFD}+k_{\mathrm{PPFD}}}\right) \times\left[\frac{\mathrm{LAI}}{(\mathrm{LAI}+a)}\right]$,

where $P_{\max }$ is maximum photosynthetic rates, PPFD is photosynthetic photon flux density, $k_{\mathrm{PPFD}}$ is the PPFD value at which GPP reaches half its maximum (half saturation constant), LAI is Leaf Area Index (see Sect. 2.2) and $a$ is a model parameter.

In the $R_{\text {eco }}$ models, we used soil temperature at $5 \mathrm{~cm}$ depth $\left(T_{5 \mathrm{~cm}}\right)$ and either WT level (Eq. 2) for Site A or volumetric moisture content (VMC) (Eq. 3) for Site B:

$$
\begin{aligned}
R_{\mathrm{eco}} & =(a+(b \times \mathrm{WT})) \\
\times & {\left[\exp \left(c \times\left(\frac{1}{T_{\mathrm{REF}-T_{0}}}-\frac{1}{T_{5 \mathrm{~cm}-}-T_{0}}\right)\right]\right.} \\
R_{\mathrm{eco}} & =\frac{a}{(1+\exp (-(\mathrm{VMC}-b) / c))} \times T_{5 \mathrm{~cm}},
\end{aligned}
$$

where $R_{\text {eco }}$ is ecosystem respiration, $T_{\mathrm{REF}}$ is reference temperature set at $283.15 \mathrm{~K}$, parameter $T_{0}$ is the (minimum) temperature at which respiration reaches zero and set here at $227.13 \mathrm{~K}$, VMC is volumetric moisture content, WT is water table depth and $a, b$ and $c$ are model parameters.

\subsubsection{Reconstruction of annual $\mathrm{CO}_{2}-\mathrm{C}$ balance}

The response functions estimated for GPP and $R_{\text {eco }}$ were used for the annual reconstruction of NEE. In combination with an hourly time series of (1) PPFD, VMC (Site B) and $T_{5 \mathrm{~cm}}$, recorded by the weather station and data loggers, (2) modelled LAI and (3) WT depths linearly interpolated from weekly measurements, GPP and $R_{\text {eco }}$ fluxes were reconstructed for each sample plot. NEE was then calculated on an hourly basis as follows: NEE $=$ GPP $-R_{\text {eco }}$ (Alm et al., 1997). Negative NEE values indicated a net uptake of $\mathrm{CO}_{2}$ from the atmosphere by the peatland and positive values indicated a net loss of $\mathrm{CO}_{2}$ to the atmosphere. The annual $\mathrm{CO}_{2}-\mathrm{C}$ balance $\left(\mathrm{g} \mathrm{C} \mathrm{m}^{-2} \mathrm{yr}^{-1}\right)$ was calculated for each sample plot by integrating the hourly NEE values over each 12 month period (Year 1: 1 April 2011 to 31 March 2012 and Year 2: 1 April 2012 to 31 March 2013).

Uncertainty in the reconstructed annual GPP and $R_{\text {eco }}$ was calculated by summing up the maximum and minimum standard errors associated with each of the model parameters (e.g. Drösler, 2005; Elsgaard et al., 2012). As NEE is not directly modelled, uncertainty in the annual NEE estimate was calculated following the law of error propagation as the square root of the sum of the squared standard errors of GPP and $R_{\text {eco }}$. Modelled $\mathrm{CO}_{2}$ fluxes, GPP and $R_{\text {eco }}$, as well environmental parameters were tested using repeated measures GLM (General Linear Models) to show any effects of sites and year and combination of site and year (IBM SPSS Statistics for Windows, Version 21.0. Armonk, NY. USA).

\subsection{Waterborne $\mathrm{C}$ exports}

Fluxes of DOC, particulate organic C (POC), and dissolved inorganic C (DIC) were determined for each site for the hydrological year beginning October 2011. For Site A, a second year of monitoring covered the hydrological year commencing October 2012. Discharge measurement, laboratory analyses and $\mathrm{C}$ flux estimation methods employed are briefly described below and detailed in Barry et al. (2014).

In order to accurately estimate waterborne $\mathrm{C}$ fluxes representative of the area on which the terrestrial GHG fluxes were conducted, runoff measurements were confined to the smallest catchment areas encompassing the GHG study sites. Field drains adjacent to each of the study sites were selected and these drained relatively small areas of between 3 and 5 ha. Critically, soils and land use within these catchments was uniform and consistent with that of the GHG study sites. Although areas outside of the study sites yielded water, this approach has advantages in that sampling is close to source, limiting the residence time between exports from the soil environment and thereby lessening the impact of processes that can alter aqueous fluxes (e.g. remineralisation and atmospheric evasion of $\mathrm{CO}_{2}$ ). Continuous level recorders (Orpheus mini, OTT Germany) and flow gauging instrumentation were installed at each site. $\mathrm{C}$ concentrations were determined at fortnightly to monthly intervals throughout each monitoring period. DOC concentration was measured by high temperature Pt-catalysed combustion on glass fibre filtered samples (Whatman GF/C; $1.7 \mu \mathrm{m}$ ), POC concentrations by loss on ignition of samples filtered onto glass fibre filters, and DIC was calculated according to Stumm and Morgan (1996), from alkalinity (gran titration), and in situ measurements of $\mathrm{pH}$, temperature and specific conductance. Annual C loads were calculated as the product of annual or seasonal flow-weighted mean concentrations and runoff volumes, corresponding to "method 5" given by Walling and Webb (1985), and DOC rainwater inputs were subtracted based on concentrations determined for rainwater during the study. Fluxes are expressed as areal rates according to catchment area. $95 \%$ confidence limits for flux estimates were calculated according to Hope et al. (1997).

As DIC reflects both $\mathrm{CO}_{2}$ derived from soil respiration and $\mathrm{C}$ derived from the atmosphere and rock weathering, total DIC exports were apportioned to reflect terrestrial organic matter dynamics alone (Stumm and Morgan, 1996; Telmer and Veizer, 1999). All $\mathrm{CO}_{2}$ above atmospheric equilibrium was considered derived from respiration of organic matter. 
The origin of $\mathrm{C}$ derived from rock weathering present as dissolved carbonates varies with respect to the $\mathrm{C}$ content of the source geology, such that $50 \%$ of the $\mathrm{C}$ present as bicarbonate from the dissolution of carbonate rocks originates from the rock, and $50 \%$ from carbonic acid (with soil respiratory/atmospheric origin). In contrast, all $\mathrm{C}$ present as bicarbonate from the dissolution of feldspars and silicate rocks originates from carbonic acid. Thus for Site B, which overlies limestone geology, half of the bicarbonate export was attributed to soil respiratory C, whereas for Site A, which overlies Precambrian Gneiss and Schist, all bicarbonate was attributed to soil respiratory $\mathrm{C}$.

\subsection{Calculation of NECB}

A full net ecosystem carbon balance (NECB) can be derived from the terrestrial $\mathrm{GHG}\left(\mathrm{CO}_{2}\right.$ and $\left.\mathrm{CH}_{4}\right)$ sources and sinks by adding fluvial $\mathrm{C}$ fluxes and $\mathrm{C}$ emissions associated with biomass removal and the livestock grazing (enteric fermentation and on-site manure deposits). The following nationally derived emission rates for $\mathrm{CH}_{4}$ from enteric fermentation were employed as detailed by O'Mara et al. (2007): $74 \mathrm{~kg}$ $\mathrm{CH}_{4}$ head $^{-1} \mathrm{yr}^{-1}$ for suckler cows; $22.4 \mathrm{~kg} \mathrm{CH}_{4}$ head $^{-1} \mathrm{yr}^{-}$ for calves; $8 \mathrm{~kg} \mathrm{CH}_{4}$ head $^{-1} \mathrm{yr}^{-1}$ for sheep.

\section{Results}

\subsection{Weather conditions}

In Year 1, Site A displayed higher precipitation $(1211 \mathrm{~mm})$ as well as a higher annual mean air temperature $\left(10.2^{\circ} \mathrm{C}\right)$ compared to Site B $\left(1003 \mathrm{~mm}\right.$; $\left.9.6^{\circ} \mathrm{C}\right)$ (Table 1). Rainfall and temperature patterns were similar with both sites having higher mean annual precipitation (7-12\%) and air temperature $(5-10 \%)$ compared to the 30-year average values (Table 1). Both sites also had cooler summer but warmer autumn and winter temperatures compared to the 30-year monthly averages. There was no significant difference between monthly mean soil temperatures between all the sites ( $p=0.801)$ (Fig. 2). In Year 2, Site A again received higher precipitation that the long-term average $(1193 \mathrm{~mm})$ driven by high values during June and July, September and October, and December and January. However, both the mean annual and monthly air temperatures were consistently below the long-term averages (by 8-9\%).

There was a typical seasonal trend in mean monthly PPFD values at both locations (Fig. 2) associated with day length and seasonal cloud cover, with the highest values observed in summer (June to August) and lowest in the winter (December to February). Annual and mean monthly PPFD values were significantly higher $(p<0.001)$ at Site B than Site A during Year 1. There was no significant difference between Year 1 and Year 2 at Site A but PPFD values were consistently higher in Year 2 during the period June-December, except for July.
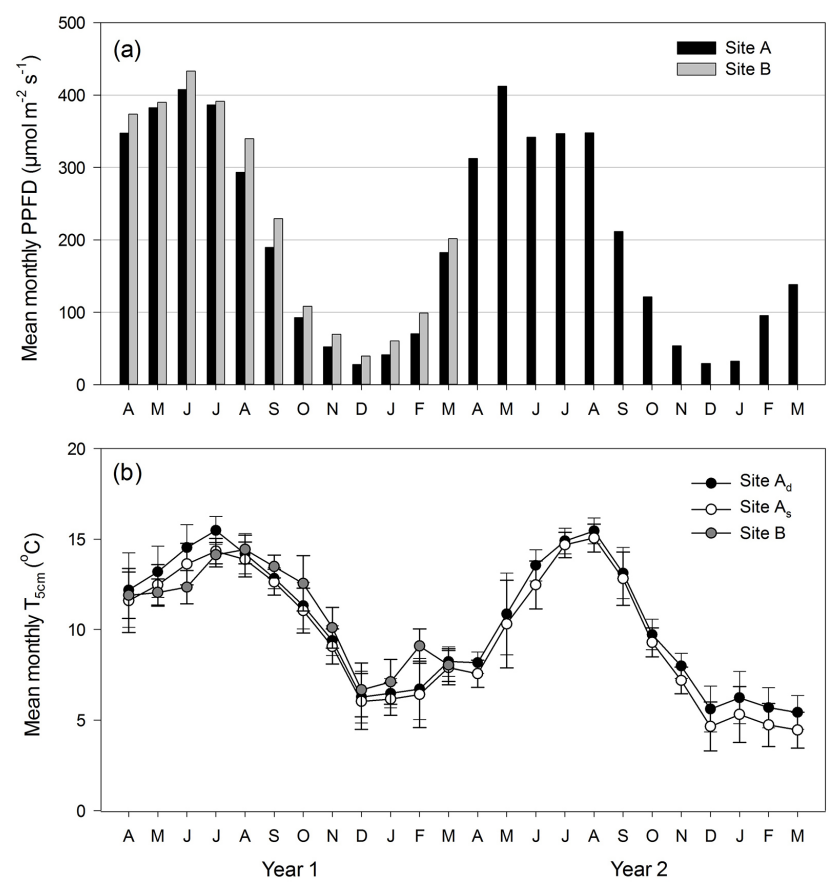

Figure 2. (a) Mean monthly Photosynthetic Photon Flux Density (PPFD) ( $\mu \mathrm{mol} \mathrm{m}{ }^{-2} \mathrm{~s}^{-1}$ ) at Site A (April 2011 to March 2013) and Site B (April 2011 to March 2012) and (b) mean monthly soil temperature at $5 \mathrm{~cm}$ depth $\left(T_{5 \mathrm{~cm}} \pm\right.$ standard deviation $)$ at Site $A_{\mathrm{d}}$, Site $A_{\mathrm{S}}$ and Site B.

Seasonality of precipitation was reflected in WT depth at Site A and soil moisture content at Site B (Fig. 3). Despite rising slightly above $-40 \mathrm{~cm}$ in winter, the monthly WT site averages at Site $A_{\mathrm{d}}$ were relatively stable and similar annual means were recorded in both years $(-47.8$ and $-47.4 \mathrm{~cm})$. Monthly means were significantly different between Sites $A_{\mathrm{d}}$ and $A_{\mathrm{S}}(p<0.001)$, the latter being characterised by seasonal fluctuations with monthly WT below $-30 \mathrm{~cm}$ during late summer/early autumn periods, rising quickly to levels above $-10 \mathrm{~cm}$ during winter periods. Despite this, the annual WT mean at Site $A_{\mathrm{s}}$ was similar between years at $-22.9 \mathrm{~cm}$ in Year 1 and $-24.2 \mathrm{~cm}$ in Year 2. At Site B, VMC averaged $47.5 \%$ and ranged from 20 to $62 \%$ with two significantly drier periods in May and August in Year 1.

\section{$3.2 \mathrm{CO}_{2}$ fluxes}

The relationships between GPP and the environmental variables differed between the study sites as demonstrated by the different model coefficients derived for Eqs. (1)-(3), and given in Table 3. GPP is strongly dependent on irradiance (PPFD) and is commonly described by a rectangular hyperbola. Seasonal variation in the photosynthetic capacity of the vegetation, described by LAI, was incorporated into the model in a manner similar to that described by Wilson et al. (2007b). A close relationship between GPP and PPFD was observed at all sites $\left(r^{2}=0.53-0.59\right)$ and the addition 

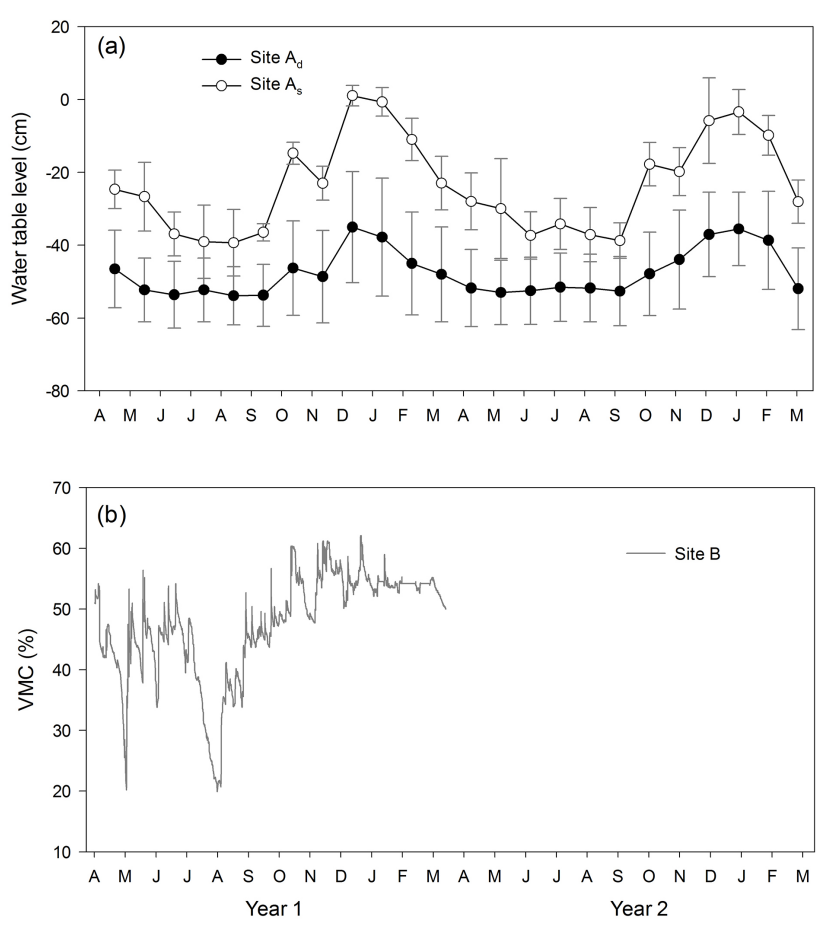

Figure 3. (a) Mean monthly water table levels (cm) at Site $A_{\mathrm{d}}$ and $A_{\mathrm{S}}$ (error bars are standard deviation of the monthly means) and (b) Volumetric Moisture Content (\% VMC) at Site B (in the surface $5 \mathrm{~cm}$ of the peat).

of the LAI term further improved the explanatory power of the model for both Site A $\left(r^{2}=0.72\right)$ and Site B $\left(r^{2}=0.85\right)$. Validation of the model showed a strong agreement between modelled versus observed GPP fluxes (Fig. 4) and independent test data $\left(r^{2}=0.86\right.$ at both Sites A and B). However, higher variation was evident in the predicted GPP fluxes at Site B, particularly at low to medium flux rates (1000$\left.3000 \mathrm{mg} \mathrm{CO}_{2} \mathrm{~m}^{-2} \mathrm{~h}^{-1}\right)$. At Site A, $R_{\text {eco }}$ was driven by $T_{5 \mathrm{~cm}}$ and WT $\left(r^{2}=0.75\right)$ and at Site B, $R_{\text {eco }}$ was controlled by VMC and $T_{5 \mathrm{~cm}}$, and this combination explained $67 \%$ of the variation. As with GPP, the relationship between observed and modelled $R_{\text {eco }}$ was generally strong (Fig. 4). At Site B, there was a tendency for the model to overestimate low flux rates and underestimate higher flux rates $\left(r^{2}=0.63\right.$ at Site A and $r^{2}=0.54$ at Site B using independent test data).

As expected, monthly estimates of GPP demonstrated clear seasonal variation with maximum rates occurring during the month of July regardless of sites and year. In Year 1, monthly GPP values were consistently higher in Site B (Fig. 5) than Site A. This was also reflected in the higher $P_{\max }$ parameter values in the GPP model (Table 3). Within Site A, monthly GPP was higher at Site $A_{\mathrm{d}}$ than Site $A_{\mathrm{s}}$ in both years. Monthly $R_{\text {eco }}$ followed the same seasonal trend as GPP, which exceeded $R_{\text {eco }}$ between April and August in Year 1 at Site $A_{\mathrm{s}}$ and similarly at Site $A_{\mathrm{d}}$ except for the month of July. NEE was positive (i.e. $\mathrm{CO}_{2}-\mathrm{C}$ source) throughout
Table 3. Estimated parameter values for gross photosynthesis (GPP) and ecosystem respiration $\left(R_{\mathrm{eco}}\right)$ models (see related equations in the text). Standard error of the model parameter in parentheses. Coefficient of determination $\left(r^{2}\right)$ values and equation number are shown. $p$-values for all parameters $<0.005$.

\begin{tabular}{lrr}
\hline Study site & Site A & Site B \\
\hline \multicolumn{2}{l}{ Model parameters } & \\
\hline GPP & & \\
\hline$P_{\max }$ & $5187.1(289.6)$ & $9055.3(379.7)$ \\
$k_{\text {PPFD }}$ & $403.9(44.1)$ & $814.61(65.1)$ \\
$a$ & $0.19(0.02)$ & $0.25(0.02)$ \\
$r^{2}$ & 0.72 & 0.85 \\
Equation No. & 1 & 1 \\
\hline$R_{\text {eco }}$ & & $104.9(6.3)$ \\
\hline$a$ & $296.5(31.1)$ & $-10.2(3.6)$ \\
$b$ & $-6.06(0.69)$ & $63.9(2.7)$ \\
$c$ & $425.3(22.1)$ & 0.67 \\
$r^{2}$ & 0.75 & 3 \\
Equation No. & 2 & \\
\hline
\end{tabular}

the winter periods as a result of a greater reduction of GPP compared to $R_{\text {eco }}$. Monthly $\mathrm{CO}_{2}$ emissions (positive NEE values) were much lower in Year 2 for 4 months (OctoberJanuary) due to lower winter temperatures (Figs. 2 and 5). In contrast $R_{\text {eco }}$ exceeded GPP for 8 months of the year at Site $\mathrm{B}$, with $\mathrm{CO}_{2}$ uptake only occurring in May through July. However, the highest monthly $\mathrm{CO}_{2}$ uptake for any plots $\left(-128 \mathrm{~g} \mathrm{C} \mathrm{m}^{-2}\right.$ month $\left.^{-1}\right)$ were observed during these months (Fig. 5).

In Year 1 , annual GPP was significantly greater $(p<0.001)$ at Site B $\left(2089 \mathrm{~g} \mathrm{CO}_{2}-\mathrm{C} \mathrm{m}^{-2} \mathrm{yr}^{-1}\right)$ compared to Sites $A_{\mathrm{d}}$ $\left(1651 \mathrm{~g} \mathrm{CO}_{2}-\mathrm{C} \mathrm{m}^{-2} \mathrm{yr}^{-1}\right)$ and $A_{\mathrm{s}}\left(1349 \mathrm{~g} \mathrm{CO}_{2}-\mathrm{C} \mathrm{m}^{-2} \mathrm{yr}^{-1}\right)$ with the latter being $35 \%$ lower than Site B (Table 4). In Year 2, annual GPP was $10 \%$ lower at Site $A_{\mathrm{s}}$ and $5 \%$ lower at Site $A_{\mathrm{d}}$ presumably in response to lower temperatures and irradiance in the spring and autumn. In Year 1, annual $R_{\text {eco }}$ at Site B $\left(2322 \mathrm{~g} \mathrm{C} \mathrm{m}^{-2} \mathrm{yr}^{-1}\right)$ was almost twice that at Site $A_{\mathrm{s}}\left(1260 \mathrm{~g} \mathrm{C} \mathrm{m}^{-2} \mathrm{yr}^{-1}\right)$ with Site $A_{\mathrm{d}}$ intermediate $\left(1736 \mathrm{~g} \mathrm{C} \mathrm{m}^{-2} \mathrm{yr}^{-1}\right)$. In Year 2, similar trends to GPP were observed with a decrease in annual $R_{\text {eco }}$ of $12 \%$ at both Sites $A_{\mathrm{d}}$ and $A_{\mathrm{s}}$ (Table 4).

Annual NEE varied between sites and years (Table 4). In Year 1 , Site $A_{\mathrm{d}}$ was a $\mathrm{CO}_{2}-\mathrm{C}$ source of $85 \mathrm{~g} \mathrm{CO}_{2}-\mathrm{C} \mathrm{m}^{-2} \mathrm{yr}^{-1}$ and Site $A_{\mathrm{S}}$ was a net sink $\left(-89 \mathrm{~g} \mathrm{CO}_{2}-\mathrm{C} \mathrm{m}^{-2} \mathrm{yr}^{-1}\right)$. However, both sites were $\mathrm{CO}_{2}-\mathrm{C}$ sinks in Year $2(-26$ and $-99 \mathrm{~g} \mathrm{CO}_{2}-\mathrm{C} \mathrm{m}^{-2} \mathrm{yr}^{-1}$ respectively). In contrast, Site B was a $\mathrm{CO}_{2}-\mathrm{C}$ source of $233 \mathrm{~g} \mathrm{CO}_{2}-\mathrm{C} \mathrm{m}^{-2} \mathrm{yr}^{-1}$. The site effect was highly significant $(p<0.001)$ between all sites in Year 1. Similar analysis performed between Site $A_{\mathrm{d}}$ and $A_{\mathrm{s}}$ for both years generated a significant site $\times$ year interaction 


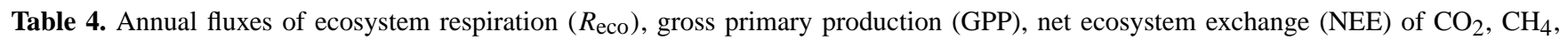
dissolved organic carbon (DOC), particulate organic carbon (POC), excess $\mathrm{CO}_{2}$ and bicarbonate $\left(\mathrm{HCO}_{3}^{-}\right)$together with biomass exports, $\mathrm{CH}_{4}$ emissions from enteric fermentation and net ecosystem carbon balance (NECB). Standard errors are shown in parentheses for all gas fluxes $R_{\mathrm{eco}}$, GPP, NEE and for fluvial fluxes. One standard deviation is shown in parentheses for all other components. Site $A_{\mathrm{d}}=$ nutrientpoor deep-drained, Site $A_{\mathrm{S}}=$ nutrient-poor shallow-drained and Site $\mathrm{B}=$ nutrient-rich drained. Positive values indicate a loss of carbon from the site and negative values indicate an uptake of carbon by the site.

\begin{tabular}{|c|c|c|c|c|c|c|c|c|c|c|c|c|}
\hline & $\begin{array}{r}R_{\text {eco }} \\
\mathrm{g} \mathrm{C} \mathrm{m}^{-2} \mathrm{yr}^{-1}\end{array}$ & $\begin{array}{r}\mathrm{GPP} \\
\mathrm{gC} \mathrm{m}^{-2} \mathrm{yr}^{-1}\end{array}$ & $\begin{array}{r}\text { NEE } \\
\mathrm{g} \mathrm{Cm}^{-2} \mathrm{yr}^{-1}\end{array}$ & $\begin{array}{r}\mathrm{CH}_{4} \\
\mathrm{~g} \mathrm{Cm}^{-2} \mathrm{yr}^{-1}\end{array}$ & $\begin{array}{l}\mathrm{CH}_{4} \text { livestock } \\
\mathrm{g} \mathrm{C} \mathrm{m}^{-2} \mathrm{yr}^{-1}\end{array}$ & $\begin{array}{l}\text { Biomass export } \\
\mathrm{g} \mathrm{C} \mathrm{m}^{-2} \mathrm{yr}^{-1}\end{array}$ & $\begin{array}{r}\mathrm{NEE}+\mathrm{Biomass}^{-} \\
\mathrm{g} \mathrm{C} \mathrm{m}^{-2} \mathrm{yr}^{-1}\end{array}$ & $\begin{array}{r}\text { DOC } \\
\mathrm{g} \mathrm{Cm}^{-2} \mathrm{yr}^{-1}\end{array}$ & $\begin{array}{r}\mathrm{POC} \\
\mathrm{g} \mathrm{Cm}^{-2} \mathrm{yr}^{-1}\end{array}$ & $\begin{array}{r}\text { Excess } \mathrm{CO}_{2} \\
\mathrm{~g} \mathrm{Cm}^{-2} \mathrm{yr}^{-1}\end{array}$ & $\begin{array}{r}\mathrm{HCO}_{3}^{-} \\
\mathrm{g} \mathrm{Cm}^{-2} \mathrm{yr}^{-1}\end{array}$ & $\begin{array}{r}\text { NECB } \\
\mathrm{g} \mathrm{Cm}^{-2} \mathrm{yr}^{-1}\end{array}$ \\
\hline \multicolumn{13}{|l|}{ Year 1} \\
\hline Site $A_{\mathrm{d}}$ & 1736 (17) & $-1651(47)$ & $85(50)$ & 0 & 3.6 & $225(60)$ & 310 & $18.1(3.2)$ & $6.4(2.7)$ & $13.4(3.2)$ & $6.1(0.6)$ & $358(111)$ \\
\hline Site $A_{\mathrm{s}}$ & $1260(49)$ & $-1349(54)$ & $-89(73)$ & $1.3(1.09)$ & 3.6 & $174(25)$ & 85 & $18.1(3.2)$ & $6.4(2.7)$ & $13.4(3.2)$ & $6.1(0.6)$ & $134(75)$ \\
\hline Site B & $2322(53)$ & $-2089(57)$ & $233(78)$ & 0 & 9.5 & $351(40)$ & 584 & $37.7(9.0)$ & $7.9(3.7)$ & $4.3(0.9)$ & $19.9(3.7)$ & $663(42)$ \\
\hline \multicolumn{13}{|l|}{ Year 2} \\
\hline Site $A_{\mathrm{d}}$ & $1535(6)$ & $-1561(50)$ & $-26(50)$ & 0 & 3.6 & $185(36)$ & 159 & $4.9(0.26)$ & $2.0(2.7)$ & $18.5(3.0)$ & $5.4(0.3)$ & $193(64)$ \\
\hline Site $A_{\mathrm{s}}$ & $1112(36)$ & $-1211(58)$ & $-99(68)$ & $1.4(1.1)$ & 3.6 & $137(28)$ & 38 & $4.9(0.26)$ & $2.0(2.7)$ & $18.5(3.0)$ & $5.4(0.3)$ & $73(56)$ \\
\hline
\end{tabular}
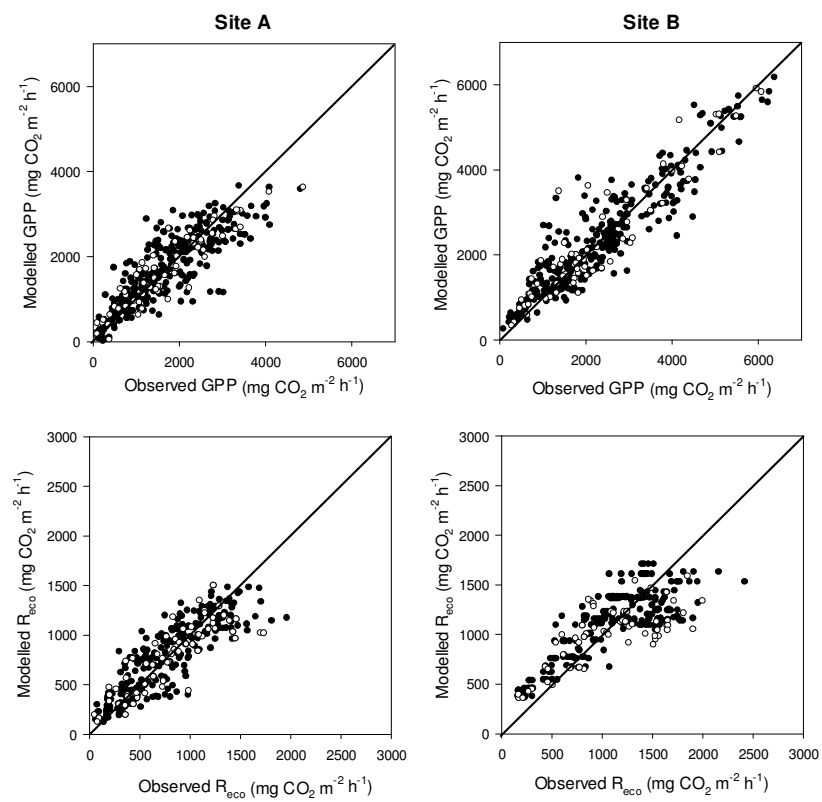

Figure 4. Relationship between observed and modelled Gross Primary Production (GPP) and Ecosystem Respiration $\left(R_{\text {eco }}\right)$ fluxes $\left(\mathrm{mg} \mathrm{CO}_{2} \mathrm{~m}^{-2} \mathrm{~h}^{-1}\right)$ for Sites A and B. Dark circles indicate data used in the construction of models and open circles indicate independent test data.

$(p<0.001)$ demonstrating that $\mathrm{CO}_{2}$ fluxes were significantly different between the sites and between years in Site A.

\subsection{Biomass production/export}

Contrasting annual GPP values between sites and between years are associated with biomass productivity. In Year 1, the cumulative production was superior at Site $\mathrm{B}\left(351 \mathrm{~g} \mathrm{C} \mathrm{m}^{-2}\right)$, with Site $A_{\mathrm{d}}$ and $A_{\mathrm{s}} 35 \%$ and $50 \%$ less productive respectively (Table 4). Biomass production in Site B started to increase sooner than Site A and was consistently higher, peaking during the warmest months (July-August) (data not shown). Biomass production also lasted for a longer pe-
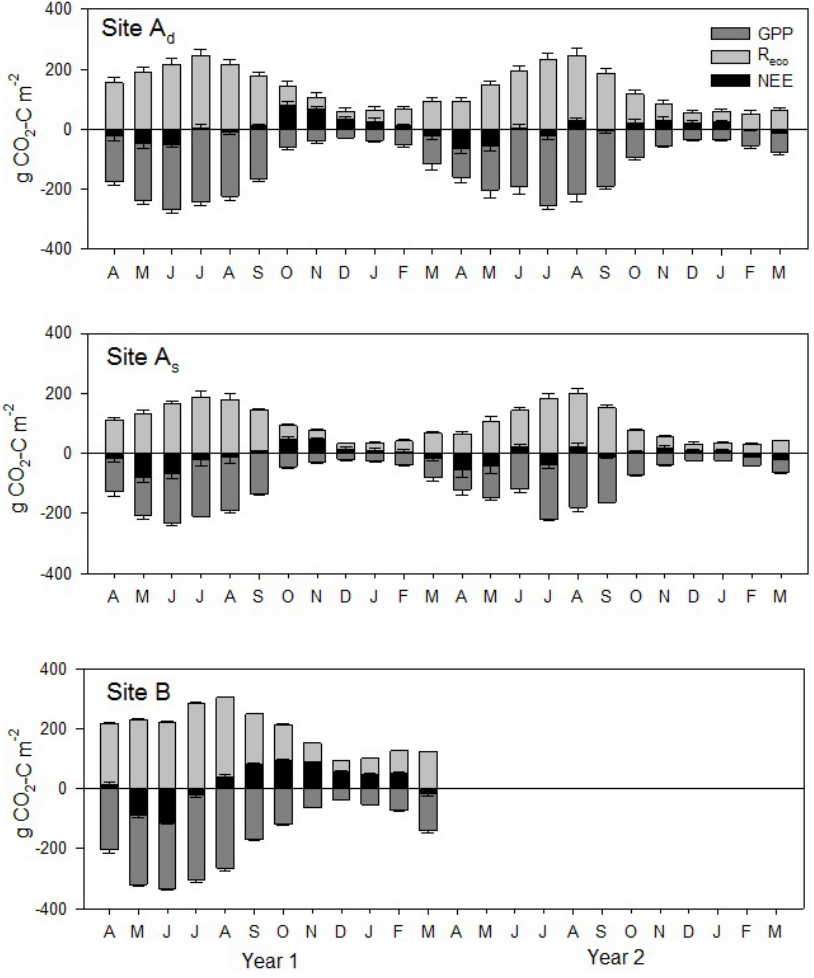

Figure 5. Monthly mean gross primary production (GPP), ecosystem respiration $\left(R_{\mathrm{eco}}\right)$ and net ecosystem exchange (NEE) $\left(\mathrm{g} \mathrm{CO}_{2}-\right.$ $\mathrm{C} \mathrm{m}^{-2}$ month $\left.^{-1}\right)$. Error bars represent \pm standard deviation. $n=7$ for Site $A_{\mathrm{d}}, n=5$ for Site $A_{\mathrm{S}}$ and $n=9$ for Site B. Negative NEE values indicate that the site was a net sink for $\mathrm{CO}_{2}-\mathrm{C}$ for that month.

riod at Site B allowing for biomass removal to take place as late as October (eight cutting events in total). Productivity was lower throughout Year 2 with poor growth during late summer months a particular feature. Lower temperatures throughout the second growing season was likely the driver behind the decrease in productivity with biomass production $18 \%$ lower at Site $A_{\mathrm{d}}$ (from 225 to $185 \mathrm{~g} \mathrm{C} \mathrm{m}^{-2}$ ) and $21 \%$ at Site $A_{\mathrm{s}}$ (from 174 to $137 \mathrm{~g} \mathrm{C} \mathrm{m}^{-2}$ ) (Table 4). Since vegetation density $\left(\right.$ stems $\mathrm{m}^{-2}$ ) was similar between the shallow- 


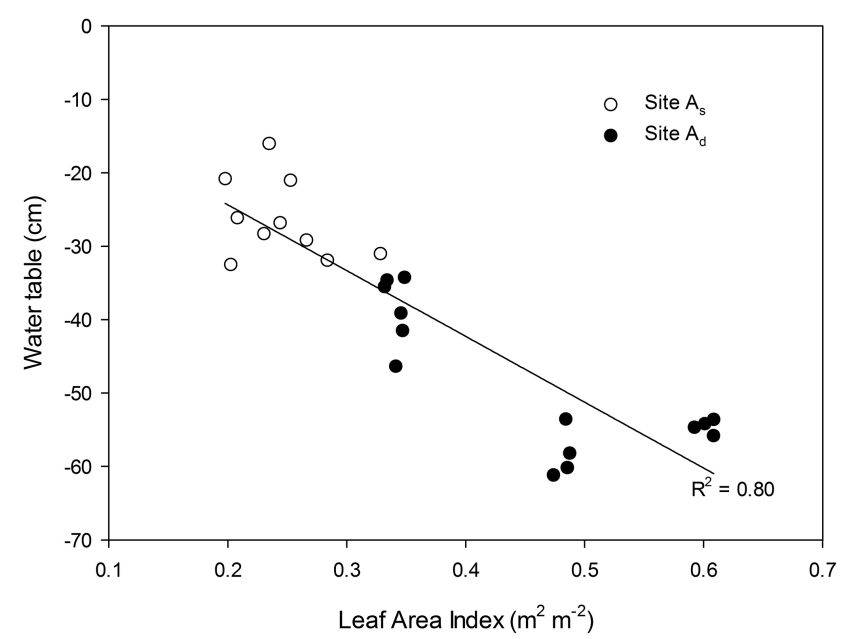

Figure 6. Relationship between mean annual water table $(\mathrm{cm})$ and mean annual Leaf Area Index (LAI) at the nutrient-poor sites $A_{\mathrm{d}}$ and $A_{\mathrm{S}}$ (Year 1 and 2 combined).

and deep-drained plots, an analysis of growth rates demonstrated that for both years, mean growth rates (over periods between grazing events) were significantly lower in Site $A_{\mathrm{s}}$ compared to $A_{\mathrm{d}}(p<0.001)$, except for the first two months of the study (Fig. 7). The contrasting productivity between all sites was also reflected in LAI values, which peaked before cutting events during the summer with higher values at $\sim 2 \mathrm{~m}^{2} \mathrm{~m}^{-2}$ for Site B compared to $\sim 1.5 \mathrm{~m}^{2} \mathrm{~m}^{-2}$ for Site $A_{\mathrm{d}}$ and $\sim 0.8 \mathrm{~m}^{2} \mathrm{~m}^{-2}$ for $A_{\mathrm{s}}$ (data not shown). In Year 2, maximum LAI at Site $A_{\mathrm{d}}$ was also consistently higher than Site $A_{\mathrm{s}}$ but the difference was reduced in comparison to Year 1 . A significant inverse relationship was found between mean annual water table and mean LAI (growing season) during both years (Fig. 6).

The nitrogen content of the vegetation was similar at both Site $A_{\mathrm{d}}$ and $A_{\mathrm{s}}(2 \%)$ but higher at Site B $(3.3 \%)$. Nitrogen export in biomass followed $\mathrm{C}$ export trends with the nutrient-rich Site B losing the highest amount at 265 (27) $\mathrm{kg} \mathrm{Nha}^{-1} \mathrm{yr}^{-1}$ compared to 107 (45) and 80 (12) $\mathrm{kg} \mathrm{Nha}^{-1} \mathrm{yr}^{-1}$ in Site $A_{\mathrm{d}}$ and Site $A_{\mathrm{s}}$ (data are mean \pm standard deviation with $n=7$ for Site $A_{\mathrm{d}}$ and $n=5$ for Site $A_{\mathrm{s}}$ ). Compared to Year $1, \mathrm{~N}$ biomass exports were 17 to $19 \%$ lower in Year 2 in Site $A_{\mathrm{d}}$ and $A_{\mathrm{s}}$ respectively.

\subsection{Methane fluxes}

Fluxes of $\mathrm{CH}_{4}$ were not detectable at the deep-drained sites, namely Site $A_{\mathrm{d}}$ and Site $\mathrm{B}$, and were relatively low at Site $A_{\mathrm{S}}$ (Fig. 8). A strong seasonal effect could be observed in both years at Site $A_{\mathrm{s}}$ (Fig. 8). $\mathrm{CH}_{4}$ fluxes followed a general trend where the highest values were observed in late summer and the lowest in winter time. However, high flux values for this site $\left(0.9\right.$ and $\left.1.4 \mathrm{mg} \mathrm{CH}_{4} \mathrm{~m}^{-2} \mathrm{~h}^{-1}\right)$ were also observed in April and November. Spatial variation in emissions at Site

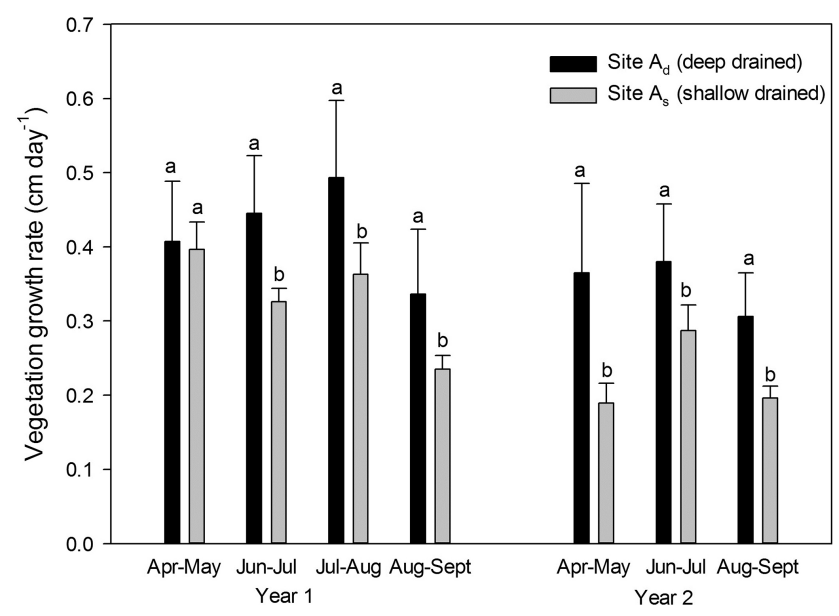

Figure 7. Vegetation mean growth rate $\left(\mathrm{cm} \mathrm{day}^{-1}\right)$ at Sites $A_{\mathrm{d}}$ and $A_{\mathrm{S}}$ during periods between simulated grazing events (cuttings) during Year 1 and 2 (vertical bars denote \pm one standard error; $n=7$ for Site $A_{\mathrm{d}}$ and $n=5$ for Site $A_{\mathrm{S}}$ ). Means with the same letter are not significantly different $(p<0.001)$.

$A_{\mathrm{s}}$ was very evident (Fig. 8) with the higher emissions associated with plots that contained Juncus effusus. No statistical relationship was observed between $\mathrm{CH}_{4}$ fluxes and any of the environmental parameters. Therefore, in order to calculate an annual $\mathrm{CH}_{4}-\mathrm{C}$ balance, linear interpolation between the observed fluxes was performed and the values integrated over a 12-month period (Beetz et al., 2013). Annual $\mathrm{CH}_{4}-\mathrm{C}$ emissions were not significantly different between years with 1.3 (1.09) $\mathrm{g} \mathrm{CH}_{4}-\mathrm{C} \mathrm{m}^{-2} \mathrm{yr}^{-1}$ in Year 1 and 1.4 (1.1) $\mathrm{g} \mathrm{CH}_{4}$ $\mathrm{C} \mathrm{m}^{-2} \mathrm{yr}^{-1}$ in Year 2 (Table 4).

\subsection{Nitrous oxide fluxes}

Fluxes of $\mathrm{N}_{2} \mathrm{O}$ were not distinguishable from zero at Site A during the monitoring period. At Site $\mathrm{B}$, a seasonal trend was observable during Year 1 with the highest values $\left(153 \mu \mathrm{g} \mathrm{N}_{2} \mathrm{O} \mathrm{m}^{-2} \mathrm{~h}^{-1}\right.$ ) observed in October (Fig. 9). $\mathrm{N}_{2} \mathrm{O}$ uptake $\left(\sim 14 \mu \mathrm{g} \mathrm{N}_{2} \mathrm{O} \mathrm{m}^{-2} \mathrm{~h}^{-1}\right)$ was observed during May. Following a fertilisation event at Site B in Year 2, $\mathrm{N}_{2} \mathrm{O}$ emissions increased considerably and reached an observed maximum of $484 \mu \mathrm{g} \mathrm{N} \mathrm{O} \mathrm{m}^{-2} \mathrm{~h}^{-1}$. As with $\mathrm{CH}_{4}$ fluxes, no statistical relationship was observed between $\mathrm{N}_{2} \mathrm{O}$ fluxes and any of the environmental parameters. Instead, linear interpolation between the observed fluxes was performed and the values integrated over a 12-month period (note that the integration period was from 1 April 2011 to 31 March 2012 and, therefore, did not cover the fertilisation experiment). Annual $\mathrm{N}_{2} \mathrm{O}-$ $\mathrm{N}$ emissions for this period were estimated at $0.16 \pm 0.34 \mathrm{~g}$ $\mathrm{N}_{2} \mathrm{O}-\mathrm{N} \mathrm{m}^{-2} \mathrm{yr}^{-1}$.

\subsection{Waterborne $\mathbf{C}$ losses}

Fluvial exports were measured at the field scale at Site A and so encompass both Sites $A_{\mathrm{d}}$ and $A_{\mathrm{s}}$. In Years 1 and 2 the 


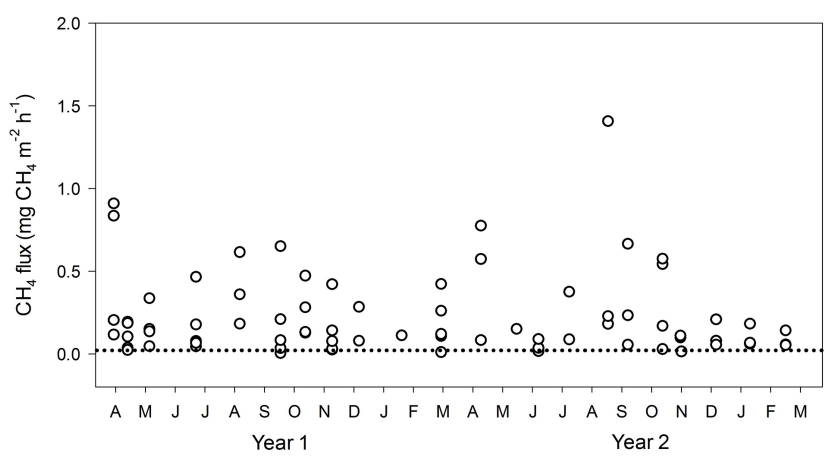

Figure 8. Measured $\mathrm{CH}_{4}$ fluxes $\left(\mathrm{mgCH}_{4} \mathrm{~m}^{-2} \mathrm{~h}^{-1}\right)$ at Site $A_{\mathrm{S}}$ (nutrient-poor, shallow-drained).

fluvial fluxes totalled $44 \mathrm{~g} \mathrm{C} \mathrm{m}^{-2} \mathrm{yr}^{-1}$ and $30.8 \mathrm{~g} \mathrm{C} \mathrm{m}^{-2} \mathrm{yr}^{-1}$ respectively. DOC export rates were $18.1 \mathrm{~g} \mathrm{C} \mathrm{m}^{-2} \mathrm{yr}^{-1}$ in Year 1 and $4.9 \mathrm{~g} \mathrm{C} \mathrm{m}^{-2} \mathrm{yr}^{-1}$ in Year 2, representing 41 and $16 \%$ of the total C flux in each year respectively (Table 4). The mean drainage water $p \mathrm{CO}_{2}$ in Years 1 and 2 respectively was 102 and 146 times in excess of atmospheric equilibrium concentrations and consequently the export of excess $\mathrm{CO}_{2}$ (above equilibrium) was substantial at 13.4 and $18.5 \mathrm{~g} \mathrm{C} \mathrm{m}^{-2} \mathrm{yr}^{-1}$ respectively. Excess $\mathrm{CO}_{2}$ represented 30 and $60 \%$ of the waterborne $\mathrm{C}$ flux each year and dominated the export of DIC (excess $\mathrm{CO}_{2}+\mathrm{HCO}_{3}^{-}$) which overall comprised 44 and $78 \%$ of the total fluvial $\mathrm{C}$ flux in each year. As with DOC, POC fluxes were also lower in Year 2, declining from $6.4 \mathrm{~g} \mathrm{C} \mathrm{m}^{-2} \mathrm{yr}^{-1}$ to $2.0 \mathrm{~g} \mathrm{C} \mathrm{m}^{-2} \mathrm{yr}^{-1}$.

The fluvial $\mathrm{C}$ flux was greater at Site $\mathrm{B}$ at $68.9 \mathrm{~g} \mathrm{C} \mathrm{m}^{-2} \mathrm{yr}^{-1}$, comprising $54 \%$ DOC, $35 \%$ DIC and $11 \%$ POC. By comparison to Site A, this waterborne C flux largely reflected a greater export of DOC, particularly relative to the second year at Site A. Despite differences in base geology between sites, the flux of DIC (estimated as derived from soil respiratory processes) was comparable to both years at Site A, but differed in that it was primarily in the form of bicarbonate ( $29 \%$ of total flux). The implication is that soil respiratory $\mathrm{CO}_{2}$ at this site yielded greater carbonate dissolution rather than accumulating in soil pore waters to high $p \mathrm{CO}_{2}$.

\subsection{NECB}

Combining the nationally derived $\mathrm{CH}_{4}$ emission rates from enteric fermentation with contemporary stocking rates at the sites yielded further emissions of $3.6 \mathrm{~g} \mathrm{C} \mathrm{m}^{-2} \mathrm{yr}^{-1}$ for Site A and $9.5 \mathrm{~g} \mathrm{C} \mathrm{m}^{-2} \mathrm{yr}^{-1}$ for Site B. Given the very low intensity farming systems at both sites, we assume the balance of $\mathrm{C}$ import/export from on-site manure deposits to be negligible (there was no fertilisation at Site $B$ in the first year). The NECB of the shallow-drained nutrient-poor grassland site was a small source in both years (134 (75) and $73(56) \mathrm{g} \mathrm{C} \mathrm{m}^{-2} \mathrm{yr}^{-1}$ ) while the deepdrained nutrient-poor site was double with 358 (111) and 193

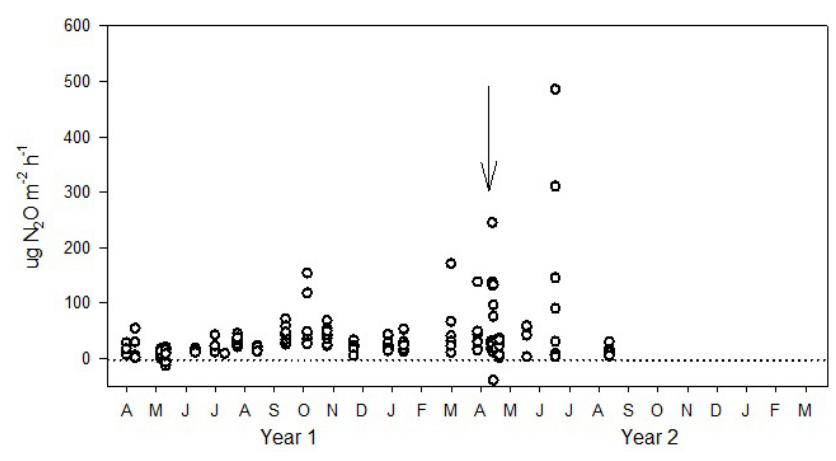

Figure 9. Measured $\mathrm{N}_{2} \mathrm{O}$ fluxes $\left(\mu \mathrm{g} \mathrm{N}_{2} \mathrm{Om}^{-2} \mathrm{~h}^{-1}\right)$ at Site B. The arrow represents a fertilisation event $\left(25 \mathrm{~kg} \mathrm{Nha}^{-1}\right)$.

(64) $\mathrm{g} \mathrm{C} \mathrm{m}^{-2} \mathrm{yr}^{-1}$. The NECB of the nutrient-rich drained site was 663 (42) $\mathrm{g} \mathrm{C} \mathrm{m}^{-2} \mathrm{yr}^{-1}$ (Table 4).

\section{Discussion}

The large amount of $\mathrm{C}$ stored in organic soils means that careful management of these soils should be a priority to reduce $\mathrm{C}$ losses. This should start with more accurate estimates of GHG fluxes and waterborne $\mathrm{C}$ losses that reflect regional variability (climatic and edaphic) but also local management practices. In this study, we have investigated contrasting permanent grasslands over organic soils in a maritime temperate climate to evaluate site effects and management practices on the GHG fluxes and waterborne $\mathrm{C}$ losses.

\subsection{Contrasting NEE and driving parameters}

Annual NEE differed significantly among sites, with the nutrient-poor shallow-drained site $\left(A_{\mathrm{s}}\right)$ a net annual sink of $\mathrm{CO}_{2}-\mathrm{C}$ in both years of the study and the nutrient-poor deepdrained site $\left(A_{\mathrm{d}}\right)$ a net sink of $\mathrm{CO}_{2}-\mathrm{C}$ in the second year. In contrast, the nutrient-rich drained Site $\mathrm{B}$ was a net annual source of $\mathrm{CO}_{2}-\mathrm{C}$. Given that there was a tendency for the $R_{\text {eco }}$ model to underestimate the higher fluxes at this site (Fig. 4), this NEE value may be a conservative estimate as it is at the lower range of data reviewed from temperate and boreal studies (e.g. Maljanen et al., 2010; Elsgaard et al., 2012; Leiber-Sauheitl et al., 2013). Annual losses of $\mathrm{CO}_{2}$ from our nutrient-rich drained Site B were more in line with those determined for low-intensity Dutch permanent grasslands on organic soils (Jacobs et al., 2007; Veenendaal et al., 2007) and for extensive wet nutrient-poor grasslands in Germany (Drösler et al., 2013). This corroborates the fact that Site B is a low-intensity grassland (no cultivation and low inputs). The importance of a "grassland type" appears even more apparent in the case of nutrient-poor sites as investigated in this study. Net annual uptake of $\mathrm{CO}_{2}-\mathrm{C}$ in both the deep-drained and shallow-drained nutrient-poor sites under investigation here contrast significantly with studies from similar site types in 
temperate climatic regions where a net annual loss of $\mathrm{CO}_{2}-\mathrm{C}$ has been reported (Drösler et al., 2013; Leiber-Sauheitl et al., 2013). The NEE values for the nutrient-poor shallowdrained sites in this study represent similar sinks (small source in some years) to those reported by Skiba et al. (2013) for grazed drained nutrient-poor organic soils (moorland) in a maritime temperate climate. Our results would therefore point to the significance of edaphic conditions as well as the low intensity management system encountered at our sites. An indication of such influences can be found in the contrasting GPP and $R_{\text {eco }}$ parameters found at all sites and which are discussed below.

\subsubsection{Productivity drivers}

The nutrient-rich grassland was the most productive with an annual GPP value in the range of those reported from Irish grasslands (Byrne et al., 2005; Gilmanov et al., 2007) and comparable to Danish grassland over organic soils (2100 to $2500 \mathrm{~g} \mathrm{C} \mathrm{m}^{-2} \mathrm{yr}^{-1}$ ) (Elsgaard et al., 2012) and to other maritime intensive grasslands over peat (2239$2403 \mathrm{~g} \mathrm{C} \mathrm{m}^{-2} \mathrm{yr}^{-1}$ ) in north Germany (Beetz et al., 2013). Despite GPP being significantly lower in the nutrient-poor sites, the values were remarkably high and more productive than similar grasslands over peat in Germany (Beetz et al., 2013; Drösler et al., 2013; Leiber-Sauheitl et al., 2013). This may be a reflection of the longer growing season due to mild winter temperatures experienced in a maritime temperate climate like Ireland (Wilson et al., 2007b) which is influenced by the North Atlantic Drift. Increased soil temperatures over the last three decades also indicate that the growing season is getting longer in Ireland (Hurtado-Uria et al., 2014). Moreover, this temperate humid climate is not associated with very high temperatures that limit productivity during the growing season via water shortage as experienced in other temperate regions. GPP was closely linked to PPFD at all studied sites and the significantly higher PPFD received by the plants at Site B (located further south than Site A) may explain some of the higher productivity there, especially given that irradiance was highest at the end of the growing season when it is one of the most dominant growth-limiting factors as soil temperature is still high (Fig. 2). However, it cannot explain the contrasting GPP between Sites $A_{\mathrm{d}}$ and $A_{\mathrm{s}}$ where plants received the same PPFD. Gross photosynthesis depends on vegetation status, commonly estimated by proxies, such as LAI, which captures well the variations in vegetation growth that occur both seasonally and as a result of grazing events (e.g. Fig. 1). Our $\mathrm{CO}_{2}$ measurement campaigns covered the full range of LAI and vegetation heights, which were always highest in the nutrient-rich site. In comparing the two nutrient-poor sites, a significant inverse relationship was found between mean annual water table and mean LAI (growing season) during both years (Fig. 6). Higher water table levels most likely reduced biomass productivity by slowing the rate of gas diffusion through the vegetation (Lo- hila, 2008), effectively inhibiting photosynthesis (decreased GPP). The lower growth rates observed in Site $A_{\mathrm{s}}$ could also be explained by the presence of wetland plant species in some of the plots, such as Juncus spp. and Equisetum spp. which have cylindrical leaves and thus affect leaf area estimations (Chen and Black, 1992; Wilson et al., 2007a).

As such, local climate and the nutrient and drainage status have been identified as the most important factors explaining the contrasting biomass productivity and consequent GPP at our sites and this was also reflected in the biomass exports. While the number of "grazing" events were similar at both Sites $A_{\mathrm{d}}$ and $A_{\mathrm{s}}$ (5 in Year 1 and 4 in Year 2), the higher productivity in the deep-drained site was reflected in larger $\mathrm{C}$ biomass exports $(30 \%$ more in Year 1 and $35 \%$ more in Year 2 compared to site $A_{\mathrm{s}}$ ). $\mathrm{N}$ biomass exports were also on average $36 \%$ higher in Site $A_{\mathrm{d}}$ over the two years. By comparison, eight "grazing" events were possible in the nutrientrich Site B. Management practice in the form of grazing regime would therefore have a greater impact on GPP than at the other sites.

\subsubsection{Respiration drivers}

Modelled annual $R_{\text {eco }}$ was significantly different among all sites and was highest at the nutrient-rich site (B) with an estimated mean value of $2322 \mathrm{~g} \mathrm{C} \mathrm{m}^{-2} \mathrm{yr}^{-1}$, which is similar to values measured for grasslands over organic soils in $\mathrm{Eu}-$ rope (Gilmanov et al., 2007; Elsgaard et al., 2012; Beetz et al., 2013). $R_{\text {eco }}$ significantly decreased with increasing soil moisture and decreasing soil temperatures in accordance with other studies on managed organic soils (Teh et al., 2011; Elsgaard et al., 2012). Soil temperatures were not significantly different among all sites and therefore did not explain the differences in $R_{\text {eco }}$. VMC varied widely at the nutrientrich site and wet-dry cycles can enhance peat degradation and therefore increase soil respiration (Aerts and Ludwig, 1997; Chow et al., 2006) as was also reflected in the higher DOC fluxes measured at that site. Furthermore, as high GPP would also result in high autotrophic respiration rates, the sustained high respiration rates at Site B, especially at the end of the growing season, might be the result of enhanced levels of heterotrophic soil respiration in the rhizosphere, known as the "priming effect" (Kuzyakov, 2006) driven by the addition of labile $\mathrm{C}$ in the form of root exudates and litter.

The two well-drained organic soils (nutrient-poor Site $A_{\mathrm{d}}$ and nutrient-rich Site B) contrasted in that, while Site $A_{\mathrm{d}}$ was less productive (20\% lower) due mainly to a lower nutrient content, it also displayed reduced $R_{\text {eco }}$ sustained through the year (30\% lower on average). Lower rates of autotrophic respiration due to lower productivity could only explain the difference during the growing season. Given that they display similar soil temperature profiles, other edaphic characteristics may be at play. When peat soils are drained, organic matter can be rapidly oxidised by aerobic metabolic processes. However, rates of aerobic decay vary widely across 
drained organic soil types even under conditions of similar climate, water table and management (Byrne et al., 2004; Couwenberg, 2011). The lower organic matter (OM) content (30 and $70 \%$ at Site $A_{\mathrm{d}}$ and B respectively) may have influenced respiration rates although Leiber-Sauheitl et al. (2013) found that $\mathrm{CO}_{2}$ emissions were not affected by lower soil organic carbon content in the surface horizon of cultivated histic soils. Leifeld et al. (2012) demonstrated that the quality of the OM at the surface of organic soils that have been drained for a long time is poor (e.g. lower polysaccharides content) and is less sensitive to $\mathrm{C}$ loss via heterotrophic respiration due to preferential metabolism of labile organic matter fractions. While OM quality was not specifically examined in this study, the soil $\mathrm{C}: \mathrm{N}$ ratios of the deep-drained sites were very similar (Table 1) suggesting similar OM quality. However, the depth of OM already exposed to oxygen would have been greater over time at Site $A_{\mathrm{d}}$ as this site has been drained for $>100$ years so that the recalcitrant OM fraction may be greater compared to Site B. Heterotrophic metabolism can also be limited by nutrient availability, so that despite the similar site characteristics and soil $\mathrm{C}: \mathrm{N}$, the greater soil nutrients and higher $\mathrm{pH}$ at Site $\mathrm{B}$ may explain the greater respiration at this site (Table 1). Indeed the elevated respiration rates are consistent with the greater soil nitrate concentrations at this site, which may partly reflect elevated nitrification rates but also that this site receives low inorganic fertiliser inputs. It should be noted that while marl is present under the peat at Site $\mathrm{B}$, the contribution of the abiotic $\mathrm{CaCO}_{3}$-derived $\mathrm{CO}_{2}$ effluxes to the annual soil $\mathrm{CO}_{2}$ fluxes is deemed marginal (Kuzyakov, 2006).

In this study, respiration rates contrasted between the two nutrient-poor sites where higher water table levels led to decreased respiration rates, which have been observed elsewhere (Leiber-Sauheitl et al., 2013; Skiba et al., 2013). The linear response of $R_{\text {eco }}$ to water table depth as modelled by Eq. (2) and the good fit between modelled and observed data for the derived models (Fig. 4) indicated that $R_{\text {eco }}$ was not restricted by very dry hydrological conditions. This is due to the relatively constant high moisture content (Irish soils are rarely subject to moisture deficit) linked to a high precipitation regime with the number of wet days well distributed throughout the year (Xu et al., 2004; Lawton et al., 2006). Soil temperature also exerted a strong influence on $R_{\text {eco }}$, as has been found in other studies and this explained the interannual variation of annual $R_{\mathrm{eco}}$ at this site. Respiration rates were reduced by $12 \%$ at both sites $A_{\mathrm{s}}$ and $A_{\mathrm{d}}$ in Year 2 which had similar water table levels but colder soil temperatures (at $5 \mathrm{~cm}$, Fig. 2) than Year 1. Interestingly, productivity was less affected by the cooler temperatures, suggesting that soil metabolism was more affected by this climatic feature than photosynthetic activity. Similarly, higher water table levels affected $R_{\text {eco }}$ more strongly than GPP (through LAI) with $27 \%$ lower annual $R_{\text {eco }}$ in the shallow-drained site in both years compared to the deep-drained site. Taken together our results demonstrate that low respiration rates controlled by higher water table levels and colder soil temperatures were the main drivers of NEE at the nutrient-poor sites. Thus, while the $\mathrm{CO}_{2}-\mathrm{C}$ sink potential of these sites may be threatened by climate change, it may be safeguarded by ensuring a shallow drainage status (water table remaining above $-25 \mathrm{~cm})$.

\subsection{Magnitude of $\mathrm{CH}_{4}$ and $\mathrm{N}_{2} \mathrm{O}$ fluxes}

Uncertainty associated with both $\mathrm{CH}_{4}$ and $\mathrm{N}_{2} \mathrm{O}$ fluxes stems from source variation (temporal and spatial) as well as limitations in measurement and methodology. As $\mathrm{CH}_{4}$ production is expected to occur mainly within the anoxic soil horizons, i.e. below the groundwater table, the absence of $\mathrm{CH}_{4}$ emissions at Sites $\mathrm{B}$ and $A_{\mathrm{d}}$ are consistent firstly with annual mean water table depths (below $-30 \mathrm{~cm}$ ) and secondly with the absence of aerenchymous plant species that can transport $\mathrm{CH}_{4}$ from the soil to the atmosphere (Couwenberg, 2009). Fluxes close to zero were also recorded from drained grasslands over peat in Germany (Drösler et al., 2013; LeiberSauheitl et al., 2013) and Denmark (Petersen et al., 2012).

The estimated mean annual $\mathrm{CH}_{4}$ fluxes for the shallowdrained nutrient-poor Site $A_{\mathrm{s}} \quad\left(18 \pm 15 \mathrm{~kg} \mathrm{CH}_{4} \mathrm{ha}^{-1} \mathrm{yr}^{-1}\right.$ over 2 years) are at the lower range of values reported for wet grasslands in Germany (Leiber-Sauheitl et al., 2013) and are only $10 \%$ of values reported for managed fen meadow and extensively managed grassland on peat in the Netherlands (Kroon et al., 2010; Schrier-Uijl et al., 2010). Our sampling frequency may have under-estimated annual emissions as some fluxes might have been missed during wetter periods. However, measurements for $\mathrm{CH}_{4}$ were carried out at all sites over a wide range of water table levels or VMC. The absence of $\mathrm{CH}_{4}$ fluxes recorded during the wetter periods in Site B in particular may be due to several reasons. Since net $\mathrm{CH}_{4}$ fluxes are measured, $\mathrm{CH}_{4}$ oxidation and consumption may be taking place within the uppermost well-aerated horizon. Suppressed methanogenesis may also occur in the deeper layers due to the abundance of electron acceptors other than oxygen, such as nitrate (Table 2). The low level or even absence of $\mathrm{CH}_{4}$ fluxes may also be due to the relatively shallow peat depth $(<1 \mathrm{~m})$ as suggested by Levy et al. (2012) and the fact that these sites have been drained for a very long time (Flasse et al., 1998). Poor quality and supply of substrates may also restrict methanogenesis (Couwenberg, 2009). Given that a recent meta-analysis has demonstrated that vegetation is the strongest explanatory parameter for $\mathrm{CH}_{4}$ flux variability (Levy et al., 2012), it is likely that the higher $\mathrm{CH}_{4}$ fluxes measured from the shallow-drained nutrient-poor sites were also a product of the presence of Juncus effusus (aerenchymous species) as seen in other studies (Petersen et al., 2012; Herbst et al., 2013). Overall, our results demonstrate that $\mathrm{CH}_{4}$ fluxes were negligible, if not absent components of the $\mathrm{C}$ balance of extensively drained grasslands over organic soils in a maritime temperate climate, and that $\mathrm{CH}_{4}$ was emitted only in 
very small amounts when the mean annual water table was around $-23 \mathrm{~cm}$.

The absence of $\mathrm{N}_{2} \mathrm{O}$ emissions from the nutrient-poor sites was consistent with the lack of artificial fertiliser use for several decades at these sites, and similar results have been reported from an extensive drained moorland in Scotland (Skiba et al., 2013). In nutrient-rich sites, the potential for $\mathrm{N}_{2} \mathrm{O}$ emissions is much higher, and is additionally forced by fertiliser applications to these more productive systems. Estimated annual $\mathrm{N}_{2} \mathrm{O}$ emissions from Site $\mathrm{B}$ are nonetheless still low by comparison with most grasslands situated over peat (closer to the IPCC Tier 1 default values for shallow-drained nutrient organic soils). This study provides further evidence that $\mathrm{N}_{2} \mathrm{O}$ fluxes are predominantly affected by the grassland management type, which is not represented in the categories with the IPCC guidelines (2014). Most investigations are carried out in intensively managed grasslands. While being nutrient-rich, Site B is still very much "extensive" given the low artificial $\mathrm{N}$ input. Our values are, however, comparable to Dutch figures reported by Langeveld et al. (1997) and van Beek et al. (2011) where grasslands had typically less fertiliser and manure inputs over time. Overall, our results are not sufficient to conclude firmly on the insignificance of $\mathrm{N}_{2} \mathrm{O}$ fluxes in extensive grassland over organic soils and further investigations in this area are warranted to ascertain the potential for large denitrification losses. Since $\mathrm{N}_{2} \mathrm{O}$ uptakes were detected on occasion (Fig. 9), $\mathrm{N}_{2} \mathrm{O}$ reductase activity could be high and therefore large dinitrogen $\left(\mathrm{N}_{2}\right)$ emissions may be possible. This study also highlights the need for further research on intensive measurement of $\mathrm{N}_{2} \mathrm{O}$ based on $\mathrm{C}: \mathrm{N}$ ratios, which may not reflect soil organic $\mathrm{C}$ degradation as seen in the contrasting ecosystem respiration measurements from our two sites with similar $\mathrm{C}: \mathrm{N}$ ratios.

\subsection{Fluvial C losses}

Studies have shown that fluvial C losses can be large components of terrestrial $\mathrm{C}$ balances at field and landscape scales, particularly where organic soils predominate (Worrall et al., 2009; Dinsmore et al., 2010; Buffam et al., 2011). Furthermore, the importance of this component can be magnified by management practices given that large increases in DOC export (51 to $118 \%$ ) can occur following drainage of such soils, related to greater DOC production under aerobic conditions and soil redox conditions during wet and dry periods (Wallage et al., 2006; Clark et al., 2009; Urbanová et al., 2011). In this study, DOC fluxes were greatest for the drained nutrientrich site but lower than values reported for drained peatland catchments in the same climatic region (Gibson et al., 2009; Rowson et al., 2010). More significantly, the 2-year mean DOC flux from the nutrient-poor site $\left(11.5 \mathrm{~g} \mathrm{C} \mathrm{m}^{-2} \mathrm{yr}^{-1}\right)$ is at the low end of values reported for temperate semi-natural peatland catchments in Ireland and the UK (Dawson et al., 2004; Dinsmore et al., 2010; Koehler et al., 2011; Kiely et al., 2014). This suggests that DOC fluxes from nutrient-poor organic soils under extensive grasslands in Ireland may be more similar to semi-natural ecosystems. Annual DOC fluxes from the nutrient-poor site were almost 4 times lower in Year 2 reaching a low value of $4.9 \mathrm{~g} \mathrm{C} \mathrm{m}^{-2} \mathrm{yr}^{-1}$. Inter-annual variability in DOC flux at this site is likely due to reduced precipitation and greater evapo-transpiration during the second hydrological year (runoff 897 and $745 \mathrm{~mm}$ in Years 1 and 2 respectively). However, the decline in DOC export from Year 1 to 2 was partially offset by a greater flux of aqueous $\mathrm{CO}_{2}$ export, implying that drier conditions were more conducive to soil OM and soil pore water OM mineralisation. In both years, the flux of DIC (derived from soil respiration) exceeded the flux of DOC, and was predominantly in the form of $\mathrm{CO}_{2}$. The high $p \mathrm{CO}_{2}$ of samples implies that accurately accounting for aqueous $\mathrm{CO}_{2}$ fluxes requires that samples are taken close to source to account for $\mathrm{C}$ that is otherwise rapidly evaded to the atmosphere, particularly with waters with low alkalinity. While the literature on aqueous inorganic $\mathrm{C}$ fluxes from agricultural catchments is not extensive, our observations are consistent with findings for small boreal streams where exports of $\mathrm{CO}_{2}$ were also substantial and atmospheric evasion of $\mathrm{CO}_{2}$ from streams was equivalent to approximately half of the total stream C flux (Wallin et al., 2013). Our findings also provide support for arguments for greater incorporation of stream C fluxes to improve regional and global C accounting (e.g. Downing et al., 2012). At Site B the DIC flux was also considerable, but comprised a lower fraction of the total. Notably this DIC export was predominately in the form of bicarbonate so that the soil respiratory origins of much of this fraction are indicated to behave more conservatively during downstream transport but nevertheless remains an important term in the terrestrial $\mathrm{C}$ balance. These results support an argument for the requirement to report other fluvial C components in GHG inventories, notably DIC and POC (e.g. Hope et al., 2001; Dinsmore et al., 2010).

\subsection{Complete NECB}

Concurrent GHG and fluvial C balance studies on organic soils have been undertaken on only a few sites worldwide and this is the first full NECB of a temperate drained organic soil under grassland. At the nutrient-rich site, NECB was relatively high $\left(663 \pm 42 \mathrm{~g} \mathrm{C} \mathrm{m}^{-2} \mathrm{yr}^{-1}\right)$ considering that the grassland is extensive and this value is greater than those reported for intensive grassland on peat in both Germany (Beetz et al., 2013) and the Netherlands (Veenendaal et al., 2007). However, the value falls within the range of annual emission rates of $410-760 \mathrm{~g} \mathrm{C} \mathrm{m}^{-2} \mathrm{yr}^{-1}$ reported by Couwenberg (2011), who reviewed several temperate drained peat soils under grassland. It should be noted, however, that the values above do not include fluvial C losses, which in this study accounted for $11 \%$ of the total NECB for the nutrient-rich site. While annual biomass exports were at the low end of literature values, e.g. $317-515 \mathrm{~g} \mathrm{C} \mathrm{m}^{-2} \mathrm{yr}^{-1}$ 
(Veenendaal et al., 2007; Beetz et al., 2013), they accounted for $53 \%$ of the NECB (Table 4). The 2-year mean NECB of the deep- and shallow-drained nutrient-poor sites were considerably smaller than the nutrient-rich site (40 and $16 \%$ respectively). Biomass exports were also the biggest components of the NECB at these sites (Table 4) and were sufficient to influence the source-sink balance of the shallow-drained site in both years and at the deep-drained site in Year 2 (i.e. shift from a NEE sink to a net source of C). Given the impact of the biomass removal on NECB, controls on grazing regimes could therefore significantly influence the $\mathrm{C}$ sink capacity of these ecosystems, as documented for an abandoned former pasture over peat in the Netherlands (Hendricks et al., 2007). The NECB of the shallow-drained nutrient-poor site is indeed consistent with values reported for an extensive grassland in Germany, which was rewetted 4 years previously (Beetz et al., 2013). However, in the case of nutrient-poor organic soils, fluvial $\mathrm{C}$ losses were not a negligible component of the overall NECB and could easily influence the final C balance of these ecosystems.

\subsection{Implications for reporting and climate change mitigation strategies}

NEE added to the $\mathrm{C}$ losses from the removal of biomass (assuming instantaneous emission of cut biomass) and averaged over a multi-annual measuring period, gives a best-possible estimate of emissions/removals and therefore the most accurate $\mathrm{CO}_{2}$-C emission factor (EF) (Couwenberg, 2011; Elsgaard et al., 2012). The EF for the nutrient-rich deep-drained grassland (Site B) was $5.84 \mathrm{tCO}_{2}-\mathrm{Cha}^{-1} \mathrm{yr}^{-1}$ which is in the range of values given in the IPCC guidance (2013): 6.1 (5.0-7.3) $\mathrm{t} \mathrm{CO}_{2}-\mathrm{Cha}^{-1} \mathrm{yr}^{-1}$ for this land use category. It corresponds well with Tier 2 country-specific EFs for permanent grassland over organic soils: $5 \mathrm{t} \mathrm{CO}_{2}-\mathrm{Cha}^{-1} \mathrm{yr}^{-1}$ in Germany (Federal Environmental Agency, 2013), 5.19 $\mathrm{t} \mathrm{CO}_{2}$ $\mathrm{Cha}^{-1} \mathrm{yr}^{-1}$ in the Netherlands (Netherlands Environmental Assessment Agency, 2009) and $5.17 \mathrm{t} \mathrm{CO}_{2}-\mathrm{Cha}^{-1} \mathrm{yr}^{-1}$ in Denmark (National Environmental Research Institute, 2013).

In contrast, our nutrient-poor sites produced much lower $\mathrm{CO}_{2}$ EFs of $2.35 \mathrm{t} \mathrm{CO}_{2}-\mathrm{Cha}^{-1} \mathrm{yr}^{-1}$ in the deep-drained and $0.62 \mathrm{t} \mathrm{CO}_{2}-\mathrm{C} \mathrm{ha}^{-1} \mathrm{yr}^{-1}$ in the shallow-drained. These figures are outside the lower range of EFs for temperate drained nutrient-poor sites in the IPCC guidance (2014): 5.3 (3.76.9) $\mathrm{t} \mathrm{CO}_{2}-\mathrm{Cha}^{-1} \mathrm{yr}^{-1}$. This default value is not further stratified between shallow and deep-drained grasslands and is based on only seven identified study sites, six of which are from Germany (Drösler et al., 2013). Nonetheless, the multisite GHG investigation reported by Drösler et al. (2013) includes nutrient-poor sites (extensive grasslands), which were a $\mathrm{CO}_{2}-\mathrm{C}$ sink (NEE minus biomass removal) in some years. In Denmark, an EF of $1.25 \mathrm{t} \mathrm{CO}_{2}-\mathrm{Cha}^{-1} \mathrm{yr}^{-1}$ is applied to non-fertilised permanent grassland. Along with the results presented here, this supports our premise highlighting considerable heterogeneity in the $\mathrm{C}$ balance of grasslands on or- ganic soils within the European temperate zone. While the stratification of default $\mathrm{CO}_{2} \mathrm{EFs}$ according to nutrient and drainage status is indeed supported by this study, variability in the impact of these factors also reflects the historical and contemporary management practices therefore advocating a progression towards the Tier 2 reporting level for countries with significant areas of organic soils under grassland.

The EF for $\mathrm{CH}_{4}$ at both the deep-drained sites (regardless of nutrient status) was zero and for the shallowdrained nutrient-poor grassland was calculated at $18 \mathrm{~kg}$ $\mathrm{CH}_{4} \mathrm{ha}^{-1} \mathrm{yr}^{-1}$. The absence of $\mathrm{CH}_{4}$ fluxes from both our well-drained organic soils is at variance with the IPCC guidance which presents an EF of $16 \mathrm{~kg} \mathrm{CH}_{4} \mathrm{ha}^{-1} \mathrm{yr}^{-1}$ for nutrient-rich and $1.8 \mathrm{~kg} \mathrm{CH}_{4} \mathrm{ha}^{-1} \mathrm{yr}^{-1}$ for nutrient-poor. This over-estimation could be compensated by using the EF for nutrient-poor drained organic soils in the case of shallowdrained nutrient-poor sites. If water table status is used as a primary factor, the only default EF provided is for shallowdrained nutrient-rich at $39 \mathrm{~kg} \mathrm{CH}_{4} \mathrm{ha}^{-1} \mathrm{yr}^{-1}$ which would also lead to a large over-estimation of $\mathrm{CH}_{4}$ fluxes.

The EF for $\mathrm{N}_{2} \mathrm{O}$ of zero at the nutrient-poor site and $1.6 \mathrm{~kg} \mathrm{~N} \mathrm{ha}^{-1} \mathrm{yr}^{-1}$ at the nutrient-rich site are both very low compared to the default EF in the IPCC guidance (2014). However, our value is likely to be conservative as the fertilisation events were not included in this figure. Despite being subject to high uncertainty, our results suggest again the likely significance of management system, especially with regard to fertilisation and stocking regime, factors which are currently missing from Tier 1 methodology.

In order to calculate an EF for DOC, it is critical to account only for the portion of DOC that could be completely mineralised and re-emitted to the atmosphere. While lake sediments can be sites for significant permanent burial of terrestrially fixed $\mathrm{C}$, in most river-lake catchments mineralisation far exceeds burial (Algesten et al., 2003), and indeed studies have shown that most of the DOC flux from drained peat catchments can be mineralised (Kölher et al., 2002; Jones et al., 2013). Despite such observations, the oceans still receive considerable inputs of terrestrial organic matter (ca. $0.4 \mathrm{Gt} \mathrm{yr}^{-1}$ according to Richey, 2004) although the very minor amounts of unambiguously terrestrial material identified in seawater and marine sediments imply that the vast majority is re-mineralised (Bauer and Bianchi, 2011). As per the updated IPCC guidance, a $90 \%$ fraction was used to calculate an overall $\mathrm{EF}$ for DOC of $22.1 \mathrm{tC} \mathrm{ha}^{-1} \mathrm{yr}^{-1}$, being much lower at the nutrient-poor site $\left(10.3 \mathrm{tC} \mathrm{ha}^{-1} \mathrm{yr}^{-1}\right)$ compared to the nutrient-rich site $\left(33.9 \mathrm{tC} \mathrm{ha}^{-1} \mathrm{yr}^{-1)}\right.$. The latter value is within the range of the default $\mathrm{EF}$ for temperate drained organic soils: 31 (19-46) $\mathrm{g} \mathrm{C} \mathrm{m}^{-2} \mathrm{yr}^{-1}$ (IPCC, 2014). Given the high inter-annual variability experienced at the nutrientpoor site, further long-term study would be warranted in order to support the development of a country-specific EF which would include a "nutrient status" stratification.

Overall, the current default EF may not be representative of the variety of grasslands over organic soils present in the 
maritime fringes of Western Europe. As only 1 full year was monitored in the nutrient-rich Site B and 2 years at Site A, a longer monitoring period to increase the range of climatic conditions and additional direct measurements from other regionally representative drained organic soils would help attain more robust emission factors by averaging inter-annual variability. In turn, this would help to implement more effectively Tier 2 methodologies for IPCC inventories. In the context of the new opportunity given by the IPCC 2013 Wetland Supplement to report rewetted drained organic soils, this study underpins the need to investigate the rewetting of high $\mathrm{C}$ content nutrient-rich organic soils under grassland in Ireland as a priority. The sustained high decomposition rates recorded at the nutrient-rich site could only be compensated by reducing microbial oxidation of peat via higher water table levels. Rewetting of these site types should therefore be a priority of any climate change mitigation strategy focusing on decreasing $\mathrm{C}$ losses from soils in Ireland. Furthermore, the neutral or C sink capacity of nutrient-poor organic soils may also be strongly affected by climate change. With higher predicted temperatures affecting peat decomposition, respiration rates might increase faster than photosynthetic assimilation due to nutrient limitation. Predicted higher precipitation for the studied region could however work in synergy with government-led actions to (1) introduce agricultural schemes to maintain a relatively high water table (above $-25 \mathrm{~cm}$ ); and (2) reduce the grazing regime to actively promote $\mathrm{C}$ uptake by these ecosystems.

\section{Concluding remarks}

This study has provided estimations of GHG fluxes and waterborne $\mathrm{C}$ losses from contrasting grasslands over organic soils and has shown that these reflect not only regional variability but also local management practices. Hence, despite the critical role of nutrient and drainage status, detailed reporting of grassland management type may provide significant additional information for more accurate regional extrapolation of $\mathrm{C}$ fluxes. The large difference in net $\mathrm{C}$ balances between the main locations stems mostly from (1) NEE estimations and (2) biomass exports, which are affected by the grazing regime. NEE estimations were driven mainly by local climate, soil fertility, water table level and potentially soil organic matter quality. These attributes are in turn intimately linked to past and current management practices in terms of drainage duration and intensity and inputs. Most Irish grasslands over organic soils were drained several decades ago and are managed as extensively grazed pastures with little or no fertilisation. Nutrient-poor sites in Ireland may not exert appreciable impacts on the atmosphere in terms of NECB, particularly where the mean annual water table remains within $-25 \mathrm{~cm}$ of the soil surface. In contrast, grassland over nutrient-rich, drained organic soils (with higher $\mathrm{C}$ content) produce much higher GHG emissions and also rep- resent hotspots for fluvial $\mathrm{C}$ losses. As the $\mathrm{C}$ balance of such sites is driven to a large extent by soil respiration, the inverse relationship of this parameter with soil moisture suggests these sites should be targeted for rewetting as a strategy to mitigate $\mathrm{C}$ emissions.

This comprehensive investigation supplied effective information for Ireland to refine emission factors currently proposed for Tier 1 drained organic soils. Longer monitoring is required to capture inter-annual variability which affects NEE in particular (being the small difference between two large terms GPP and $R_{\text {eco }}$ ) (Drösler et al., 2008). While a "grassland type" stratification, representing various management systems, may not be warranted at international guidelines levels, national research should be extended to other sites to provide more accurate emissions from extensive drained organic soils pastures and help Ireland progress towards Tier 2 methodologies.

Acknowledgements. We wish to thank the farmers who hosted the experimental sites. This work was funded by the Irish Environmental Protection Agency (EPA): Climate Change Research Programme 2006-2013, funded as part of the Strategy for Science, Technology and Innovation and the National Development Plan 2007-2013. Thanks are due to Phillip O'Brien (EPA) for his support and guidance, and to Gerard Moser (JLU, Giessen) for help with the gas analysis. We are also grateful to G. Wohlfahrt, L. Elsgaard and two anonymous referees for their critical comments of an earlier draft.

Edited by: G. Wohlfahrt

\section{References}

Aerts, R. and Ludwig, F.: Water table changes and nutritional status affect trace gas emissions from laboratory columns of peatland soils, Soil Biol. Biochem., 29, 1691-1698, 1997.

Algesten, G., Sobek, S., Bergström, A.-K., Ågren, A., Tranvik, L. J., and Jansson, M.: Role of lakes for organic carbon cycling in the boreal zone., Glob. Change Biol., 10, 141-147, 2003.

Alm, J., Talanov, A., Saarnio, S., Silvola, J., Ikkonen, E., Aaltonen, H., Nykänen, H., and Martikainen, P. J.: Reconstruction of the carbon balance for microsites in a boreal oligotrophic pine fen, Finland, Oecologia, 110, 423-431, 1997.

Alm, J., Shurpali, N. J., Tuittila, E.-S., Laurila, T., Maljanen, M., Saarnio, S., and Minkkinen, K.: Methods for determining emission factors for the use of peat and peatlands - flux measurements and modelling, Boreal Environ. Res., 12, 85-100, 2007.

Barry, C. D., Foy, R. H., Wilson, D., Müller, C., and Renou-Wilson, F.: Magnitude, form and bioavailability of fluvial carbon exports from Irish organic soils under pasture, Aquat. Sci., submitted, 2014.

Bauer, J. E. and Bianchi, T. S.: Dissolved organic carbon cycling and transformation, in: Treatise on estuarine and coastal science, edited by: Wolanski, E. and Mcluski, D. S., 5, 7-67, Academic Press, Waltham, 2011.

Beetz, S., Liebersbach, H., Glatzel, S., Jurasinski, G., Buczko, U., and Höper, H.: Effects of land use intensity on the full 
greenhouse gas balance in an Atlantic peat bog, Biogeosciences, 10, 1067-1082, doi:10.5194/bg-10-1067-2013, 2013.

Buffam, I., Turner, M. G., Desai, A. R., Hanson, P. C., Rusak, J. A., and Lottig, N. R.: Integrating aquatic and terrestrial components to construct a complete carbon budget for a north temperate lake district, Glob. Change Biol., 17, 1193-1211, 2011.

Byrne, K. A., Chojnicki, B., Christensen, T. R., Droesler, M., Freibauer, A., Friborg, T., Frolking, S., Lindroth, A., Mailhammer, J., Malmer, N., Selin, P., Turunen, J., Valentini, R., and Zetterberg, L.: EU peatlands: Current carbon stocks and trace gas fluxes, CarboEurope - GHG, 2004.

Byrne, K. A., Kiely, G., and Leahy, P.: $\mathrm{CO}_{2}$ fluxes in adjacent new and permanent temperate grasslands, Agr. Forest Meteorol., 135, 82-92, 2005.

Chen, J. M. and Black, T. A.: Defining leaf area index for non-flat leaves, Plant Cell Environ., 15, 421-429, 1992.

Chow, A. T., Tanji, K. K., Gao, S., and Dahlgren, R. A.: Temperature, water content and wet-dry cycle effects on DOC production and carbon mineralisation in agricultural peat soils, Soil Biol. Biochem., 38, 477-488, 2006.

Clark, J. M., Ashley, D., Wagner, M., Chapman, P. J., Lane, S. N., Evans, C. D., and Heathwaite, A. L.: Increased temperature sensitivity of net DOC production from ombrotrophic peat due to water table draw-down, Glob. Change Biol., 15, 794-807, 2009.

Couwenberg, J.: Methane emissions from peat soils (organic soils, histosols). Facts, MRV-ability, emission factors, Wetlands International, 14 pp., 2009.

Couwenberg, J.: Greenhouse gas emissions from managed peat soils: is the IPCC reporting guidance realistic?, Mires and Peat, 8, Article 2, 01-10, 2011.

Dawson, J. J. C. and Smith, P.: Carbon losses from soil and its consequences for land-use management, Sci. Total Environ., 382, 165-190, 2007.

Dawson, J. J. C., Billet, M., Hope, D., Palmer, S. M., and Deacon, C.: Sources and sinks of aquatic carbon in a peatland stream continuum, Biogeochemistry, 70, 71-92, 2004.

Dinsmore, K. J., Billet, M. F., Skiba, U. M., Rees, R. M., Drewer, J., and Helfter, C.: Role of the aquatic pathway in the carbon and greenhouse gas budgets of a peatland catchment, Glob. Change Biol., 16, 2750-2762, 2010.

Downing, J. A., Cole, J. J., Duarte, C. M., Middelburg, J. J., Melack, J., Prairie, Y. T., Kortelainen, P., Striegl, R. G., McDowell, W. H., and Tranvik, L.: Global abundance and size distribution of streams and rivers, Inland Waters, 2, 229-236, 2012.

Drösler, M.: Trace gas exchange and climatic relevance of bog ecosystems, southern Germany, Ph.D thesis, Department für Ökologie, Universität München, 182 pp., 2005.

Drösler, M., Adelmann, W., Augustin, J., Bergman, L., Beyer, C., Chojnicki, B. H., Förster, C., Freibauer, A., Giebels, M., Gorlitz, S., Hoper, H., Kantelhardt, J., Lieberscbach, H., HahnSchöfl, M., Minke, M., Petschow, U., Pfadenhauer, J., Schaller, L., Schagner, P., Sommer, M., Thuile, A., and Wehrhan, M.: Klimaschutz furch Moorschutz in der Praxis, http://literatur.ti. bund.de/digbig_extern/bitv/dn049337.pdf (last access: 1 February 2014), Thunen, Institut fur Agrarklimaschutz, 2013.

Drösler, M., Freibauer, A., Christensen, T. R., and Friborg, T.: Observations and status of peatland greenhouse gas emissions in Europe, in: The Continental-Scale Greenhouse Gas Balance of
Europe, edited by: Dolman, A. J., Freibauer, A., and Valentini, R., Springer, New York, 2008.

Duffy, P., Hanley, E., Hyde, B., O’Brien, P., Ponzi, J., Cotter, E., and Black, K.: National Inventory Report 2013. Greenhouse gas emissions 1990-2011 reported to the United Nations Framework Convention on Climate Change, 360 pp., 2013.

Eaton, J. M., McGoff, N. M., Byrne, K. A., Leahy, P., and Kiely, G.: Land cover change and soil organic carbon stocks in the Republic of Ireland 1851-2000, Clim. Change, 91, 317-334, 2008.

Elsgaard, L., Gorres, C.-M., Hoffmann, C. C., Blicher-Mathiesen, G., Schelde, K., and Petersen, S. O.: Net ecosystem exchange of $\mathrm{CO}_{2}$ and carbon balance for eight temperate organic soils under agricultural management, Agr. Ecosyst. Environ., 162, 5267, 2012.

EPA: Ireland's Environment 2008, Environmental Protection Agency, Wexford, Ireland, 2008.

Eurostat: http://epp.eurostat.ec.europa.eu/statistics_explained/ index.php/Agriculture_-_greenhouse_gas_emission_statistics, last access: 7 November 2013.

FAO: World Reference Base for Soil Resources, World Soil Resources Report No. 84, FAO, Rome, 1998.

FAO: http://faostat.fao.org/ (last access: 25 November 2013), 2013a.

FAO: http://faostat3.fao.org/faostat-gateway/go/to/browse/G2/GC/ E (last access: September 2013), 2013b.

Federal Environmental Agency: Submission under the United Nations Framework Convention on Climate Change and the Kyoto Protocol 2013, Umweltbundesamt, Dessau-Rosslau, Germany, 2013.

Feehan, J., O’Donovan, G., Renou-Wilson, F., and Wilson, D.: The Bogs of Ireland - An Introduction to the Natural, Cultural and Industrial Heritage of Irish Peatlands, 2nd Edn., Digital Format, University College Dublin, Dublin, 2008.

Flasse, H., Wild, U., Klemisch, M., and Pfadenhauer, J.: Nitrous oxide and methane fluxes from organic soils under agriculture, Eur. J. Soil Sci., 49, 327-335, 1998.

Freibauer, A., Rounsevell, M. D. A., Smith, P., and Verhagen, A.: Carbon sequestration in the agricultural soils of Europe, Geoderma, 122, 1-23, 2004.

Garnett, M. H., Ineson, P., Stevenson, A. C., and Howard, D. C.: Terrestrial organic carbon storage in a British moorland, Glob. Change Biol., 7, 375-388, 2001.

Gibson, H. S., Worrall, F., Burt, T., and Adamson, J. K.: DOC budgets of drained peat catchments - Implications for DOC production in peat soils, Hydrol. Process., 23, 1901-1911, 2009.

Gilmanov, T. G., Soussana, J. F., Aires, L., Allard, V., Ammann, C., Balzarolo, M., Garcza, Z., Bernhofer, C., Campbell, C., Cernusca, A., Cescatti, A., Clifton-Brown, J., Dirks, B. O. M., Dore, S., Eugster, W., Fuhrer, J., Gimeno, C., Gruenwald, T., Haszpra, L., Hensen, A., Ibrom, A., Jacobs, A. F. G., Jones, M. B., Lanigan, G., Laurila, T., Lohila, A., Manca, G., Marcolla, B., Nagy, Z., Pilegaard, K., Pinter, K., Pio, C., Raschi, A., Rogiers, N., Sanz, M., Stefani, P., Sutton, M., Tuba, Z., Valentini, R., Williams, M. L., and Wohlfahrt, G.: Partitioning European grassland net ecosystem $\mathrm{CO}_{2}$ exchange into gross primary productivity and ecosystem respiration using light response function analysis, Agr. Ecosyst. Environ., 121, 93-120, 2007. 
Gorham, E.: Northern peatlands: role in the carbon cycle and probable responses to climatic warming, Ecol. Appl., 1, 182-195, 1991.

Görres, C. M., Kutzbach, L., and Elsgaard, L.: Comparative modeling of annual $\mathrm{CO}_{2}$ flux of temperate peat soils under permanent grassland management, Agr. Ecosyst. Environ., 186, 64-76, 2014.

Hammond, R. F.: The peatlands of Ireland. Soil Survey Bulletin No. 35, An Foras Taluntais, Dublin, Ireland, 1981.

Hendriks, D. M. D., van Huissteden, J., Dolman, A. J., and van der Molen, M. K.: The full greenhouse gas balance of an abandoned peat meadow, Biogeosciences, 4, 411-424, doi:10.5194/bg-4411-2007, 2007.

Herbst, M., Friborg, T., Schelde, K., Jensen, R., Ringgaard, R., Vasquez, V., Thomsen, A. G., and Soegaard, H.: Climate and site management as driving factors for the atmospheric greenhouse gas exchange of a restored wetland, Biogeosciences, 10, 39-52, doi:10.5194/bg-10-39-2013, 2013.

Hope, D., Billett, M. F., and Cresser, M. S.: Exports of organic carbon in two river systems in NE Scotland, J. Hydrol., 193, 61-82, 1997.

Hope, D., Palmer, S. M., Billett, M. F., and Dawson, J. J. C.: Carbon dioxide and methane evasion from a temperate peatland stream, Limnol. Oceanogr., 46, 847-857, 2001.

Hurtado-Uria, C., Hennessy, d., Shalloo, L., O'Connor, D., and Delaby, L.: Relationships between meteorological data and grass growth over time in the south of Ireland, Irish Geography, 1-27, doi:10.1080/00750778.2013.865364, 2014.

IPCC: IPCC Guidelines for National Greenhouse Gas Inventories. Prepared by the National Greenhouse Gas Inventories programme, IGES, Japan, 2006.

IPCC: 2013 Supplement to the 2006 IPCC Guidelines for National Greenhouse Gas Inventories: Wetlands, editd by: Hiraishi, T., Krug, T., Tanabe, K., Srivastava, N., Baasansuren, J., Fukuda, M., and Troxler, T. G., IPCC, Switzerland, 2014.

Jacobs, C. M. J., Jacobs, A. F. G., Bosveld, F. C., Hendriks, D. M. D., Hensen, A., Kroon, P. S., Moors, E. J., Nol, L., SchrierUijl, A., and Veenendaal, E. M.: Variability of annual $\mathrm{CO}_{2}$ exchange from Dutch grasslands, Biogeosciences, 4, 803-816, doi:10.5194/bg-4-803-2007, 2007.

Jones, T., Jones, D., and Evans, C.: Conversion of waterborne DOC to $\mathrm{CO}_{2}$ - results of laboratory experiments. In: Emissions of greenhouse gases associated with peatland drainage waters: Report to Defra under project SP1205: greenhouse gas emissions associated with non gaseous losses of carbon from peatlands fate of particulate and dissolved carbon, Department of Environment, Food and Rural Affairs, UK, 2013.

Kiely, G., Leahy, P., Lewis, C., Xu, Z. H., Zhang, C., He, Y., Dao, L., Golden, N., Zi, T., and Albertson, J.: Interactions of soil hydrology, land use and climate change and their impact on soil quality (SoilH), Environmental Protection Agency, Johnstown Castle, Co. Wexford, Ireland, 60 pp., 2014.

Koehler, A.-K., Sottocornola, M., and Kiely, G.: How strong is the current carbon sequestration of an Atlantic blanket bog?, Glob. Change Biol., 17, 309-319, 2011.

Kölher, S., Buffam, I., Jonsson, A., and Bishop, K.: Photochemical and microbial processing of stream and soil water dissolved organic matter in boreal forested catchment in northern Sweden, Aquat. Sci., 64, 1-13, 2002.
Kroon, P. S., Schrier-Uijl, A. P., Hensen, A., Veenendaal, E. M., and Jonker, H. J. J.: Annual balances of $\mathrm{CH}_{4}$ and $\mathrm{N}_{2} \mathrm{O}$ from a managed fen meadow using eddy covariance flux measurements, Eur. J. Soil Sci., 61, 773-784, 2010.

Kuzyakov, Y.: Sources of $\mathrm{CO}_{2}$ efflux from soil and review of partitioning methods, Soil Biol. Biochem., 38, 425-448, 2006.

Laine, A., Riutta, T., Juutinen, S., Väliranta, M., and Tuittila, E.-S.: Acknowledging the spatial heterogeneity in modelling / reconstructing carbon dioxide exchange in a northern aapa mire, Ecol. Model., 220, 2646-2655, 2009.

Langeveld, C. A., Segers, R., Dirks, B. O. M., Van den Pol-van Dasselaar, A., Velthof, G. L., and Hensen, A.: Emissions of $\mathrm{CO}_{2}$, $\mathrm{CH}_{4}$ and $\mathrm{N}_{2} \mathrm{O}$ from pasture on drained peat soils in the Netherlands, Eur. J. Agron., 7, 35-42, 1997.

Lawton, D., Leahy, P., Kiely, G., Byrne, K. A., and Calanca, P.: Modeling of net ecosystem exchange and its components for a humid grassland ecosystem, J. Geophys. Res., 111, G04013, doi:04010.01029/02006JG000160, 2006.

Leiber-Sauheitl, K., Fuß, R., Voigt, C., and Freibauer, A.: High $\mathrm{CO}_{2}$ fluxes from grassland on histic Gleysol along soil carbon and drainage gradients, Biogeosciences, 11, 749-761, doi:10.5194/bg-11-749-2014, 2014.

Levy, P. E., Burden, A., Cooper, M. D. A., Dinsmore, K. J., Drewer, J., Evans, C., Fowler, D., Gaiawyn, J., Gray, A., Jones, S. K., Jones, T., McNamara, N. P., Mills, R., Ostle, N., Sheppard, L. J., Skiba, U., Sowerby, A., Ward, S. E., and Zieliński, P.: Methane emissions from soils: synthesis and analysis of a large UK data set, Glob. Change Biol., 18, 1657-1669, 2012.

Lohila, A.: Carbon dioxide exchange on cultivated and afforested boreal peatlands, Finnish Meteorological Institute Contributions, 73, 1-47, 2008.

Maljanen, M., Sigurdsson, B. D., Guðmundsson, J., Óskarsson, H., Huttunen, J. T., and Martikainen, P. J.: Greenhouse gas balances of managed peatlands in the Nordic countries - present knowledge and gaps, Biogeosciences, 7, 2711-2738, doi:10.5194/bg7-2711-2010, 2010.

Met Eireann: http://www.met.ie, last access: October 2013.

Mills, G.: Modelling the water budget of Ireland - evapotranspiration and soil moisture, Irish Geography, 33, 99-116, 2000.

National Environmental Research Institute: Denmark's National Inventory Report 2013, National Environmental Research Institute, Aarhus University, Denmark, 2013.

Netherlands Environmental Assessment Agency: Greenhouse Gas Emissions in the Netherlands 1990-2007. PBL report 500080012/2009, PBL, Ah Bilthoven, the Netherlands, 2009.

Nieveen, J. P., Campbell, D. I., Schipper, L. A., and Blair, I. J.: Carbon exchange of grazed pasture on a drained peat soil, Glob. Change Biol., 11, 607-618, 2005.

Norman, J. M. and Campbell, G. S.: Canopy structure, in: Plant Physiological Ecology, edited by: Pearcy, R. W., Ehleringer, J., Mooney, H. A., and Rundel, P. W., Chapman and Hall, New York, 1989.

O’Mara, F., Ryan, M., Connolly, J., O’Tool, P., Carton, O., Lenehan, J. J., Lovett, D., Hyde, B., Jordan, E., and Hawkins, M.: Estimation of emissions of greenhouse gases from agriculture and strategies for their reduction. synthesis report, EPA, Johnstown Castle, Wexford, Ireland, 18 pp., 2007.

Parish, F., Sirin, A., Charman, D., Joosten, H., Minayeva, T., Silvius, M., and Stringer, I.: Assessment on peatlands, biodiversity 
and climate change. Main report, Global Environment Centre, Kuala Lumpur and Wetlands International, Wageningen, 179 pp., 2008.

Petersen, S. O., Hoffmann, C. C., Schäfer, C.-M., BlicherMathiesen, G., Elsgaard, L., Kristensen, K., Larsen, S. E., Torp, S. B., and Greve, M. H.: Annual emissions of $\mathrm{CH}_{4}$ and $\mathrm{N}_{2} \mathrm{O}$, and ecosystem respiration, from eight organic soils in Western Denmark managed by agriculture, Biogeosciences, 9, 403-422, doi:10.5194/bg-9-403-2012, 2012.

Renou-Wilson, F., Bolger, T., Bullock, C., Convery, F., Curry, J. P., Ward, S., Wilson, D., and Müller, C.: BOGLAND - Sustainable Management of Peatlands in Ireland, STRIVE Report No 75 prepared for the Environmental Protection Agency (EPA), Johnstown Castle, Co. Wexford, 157 pp., 2011.

Richey, J. E.: Pathways of atmospheric $\mathrm{CO}_{2}$ through fluvial systems, in: The global C cycle, edited by: Field, C. B. and Raupach, M. R., Scope, Island Press, Washington DC, 2004.

Rowson, J. G., Gibson, H. S., Worrall, F., Ostle, N., Burt, T. P., and Adamson, J. K.: The complete carbon budget of a drained peat catchment, Soil Use Manage., 26, 261-273, 2010.

Schrier-Uijl, A., Kroon, P. S., Leffelaar, P. A., von Huissteden, J. C., Berendse, F., and Veenendaal, E. M.: Methane emissions in two drained peat agro-ecosystems with high and low agricultural intensity, Plant Soil, 329, 509-520, 2010.

Schrier-Uijl, A. P., Kroon, P. S., Hendriks, D. M. D., Hensen, A., Van Huissteden, J. C., Leffelaar, P. A., Berendse, F., and Veenendaal, E. M.: Agricultural peat lands; towards a greenhouse gas sink - a synthesis of a Dutch landscape study, Biogeosciences Discuss., 10, 9697-9738, doi:10.5194/bgd-10-9697-2013, 2013.

Skiba, U., Jones, S. K., Drewer, J., Helfter, C., Anderson, M., Dinsmore, K., McKenzie, R., Nemitz, E., and Sutton, M. A.: Comparison of soil greenhouse gas fluxes from extensive and intensive grazing in a temperate maritime climate, Biogeosciences, 10, 1231-1241, doi:10.5194/bg-10-1231-2013, 2013.

Smith, P., Martino, D., Cai, Z., Gwary, D., Janzen, H. H., Kumar, P., McCarl, B., Ogle, S. M., O’Mara, F., Rice, C., Scholes, B., and Sirotenko, O.: Agriculture, in: Climate Change 2007: Mitigation. Contribution of Working Group III to the Fourth Assessment Report of the Intergovernmental Panel on Climate Change, edited by: Metz., B., Davidson, P. R., Bosch, P. R., Dave, R., and Meyer, L. A., Cambridge University Press, Cambridge, UK, 2007.

Stumm, W. and Morgan, J. J.: Aquatic chemistry, chemical equilibria and rates in natural waters, John Wiley \& Sons, New York, 1996.

Teh, Y., Silver, W., Sonnentag, O., Detto, M., Kelly, M., and Baldocchi, D.: Large greenhouse gas emissions from a temperate peatland pasture, Ecosystems, 14, 311-325, 2011.

Telmer, K. and Veizer, J.: Carbon fluxes, $p \mathrm{CO}_{2}$ and substrate weathering in a large northern river basin, Canada: carbon isotope perspectives, Chem. Geol., 159, 61-86, 1999.
Tomlinson, R. W.: Soil carbon stocks and changes in the Republic of Ireland, J. Environ. Manage., 76, 77-93, 2005.

Urbanová, Z., Picek, T., and Bárta, J.: Effect of peat re-wetting on carbon and nutrient fluxes, greenhouse gas production and diversity of methanogenic archaeal community, Ecol. Eng., 37, 10171026, 2011.

van Beek, C. L., Pleijter, M., and Kuikman, P. J.: Nitrous oxide emissions from fertilized and unfertilized grasslands on peat soil, Nutr. Cycl. Agroecosys., 89, 453-461, 2011.

Veenendaal, E. M., Kolle, O., Leffelaar, P. A., Schrier-Uijl, A. P., Van Huissteden, J., Van Walsem, J., Möller, F., and Berendse, F.: $\mathrm{CO}_{2}$ exchange and carbon balance in two grassland sites on eutrophic drained peat soils, Biogeosciences, 4, 1027-1040, doi:10.5194/bg-4-1027-2007, 2007.

Wallage, Z. E., Holden, J., and McDonald, A. T.: Drain blocking: an effective treatment for reducing dissolved organic carbon loss and water discolouration in a drained peatland, Sci. Total Environ., 367, 811-821, 2006.

Wallin, M. B., Grabs, T., Buffam, I., Laudon, H., Ågren, A., Oquist, G., and Bishop, K.: Evasion of $\mathrm{CO}_{2}$ from streams - The dominant component of the carbon export through the aquatic conduit in a boreal landscape, Glob. Change Biol., 19, 785-797, 2013.

Walling, D. E. and Webb, B. W.: Estimating the discharge of contaminants to coastal waters by rivers - some cautionary comments, Mar. Pollut. Bull., 16, 488-492, 1985.

Wilson, D., Alm, J., Riutta, T., Laine, J., Byrne, K. A., Farrell, E. P., and Tuittila, E.-S.: A high resolution green area index for modelling the seasonal dynamics of $\mathrm{CO}_{2}$ exchange in vascular plant peatland communities, Plant Ecol., 190, 37-51, 2007a.

Wilson, D., Tuittila, E.-S., Alm, J., Laine, J., Farrell, E. P., and Byrne, K. A.: Carbon dioxide dynamics of a restored maritime peatland, Ecoscience, 14, 71-80, 2007b.

Wilson, D., Müller, C., Farrell, C., A., Hepp, S., and Renou-Wilson, F.: Rewetted industrial cutaway peatlands in western Ireland: prime location for climate change mitigation?, Mires and Peat, 11, Article 01, 01-22, http://www.mires-and-peat.net/ (last access: 25 November 2013), $2013 \mathrm{a}$.

Wilson, D., Müller, C., and Renou-Wilson, F.: Carbon emissions and removals from Irish peatlands: current trends and future mitigation measures, Irish Geography, 46, 1-23, doi:10.1080/00750778.2013.848542, 2013b.

Worrall, F., Burt, T. P., Rowson, J. G., Warburton, J., and Adamson, J. K.: The multi-annual carbon budget of a peat-covered catchment, Sci. Total Environ., 407, 4084-4094, 2009.

$\mathrm{Xu}$, L., Baldocchi, D., and Tang, J.: How soil moisture, rain pulses and growth alter the response of ecosystem respiration to temperature, Global Biogeochem. Cy., 18, 1-10, 2004. 